Pierpaolo Giannoccolo

\title{
The Brain Drain. A Survey of the Literature
}

\author{
Preliminary Version \\ Last Update: 31August 2004
}

\begin{abstract}
This paper reviews the theoretical and empirical literature on Brain Drain (BD). We propose an ideal path that links the first studies with the most recent ones. In this development, the literature on $\mathrm{BD}$ focuses on a variety of economic and social issues and recalls to national and international debates.

This paper uses more than 350 articles from a variety of sources. The sources are specialized professionals journals, internet research engines, governmental publications and newspapers.

In the first part we analyse briefly the $\mathrm{BD}$, its different definitions and the historical roots of the $\mathrm{BD}$. This part shows that the BD is a wide and complex phenomenon.

In the second part, we propose an ideal path to interpret the literature. This part analyses how $\mathrm{BD}$ is linked to political and social events, according to the Economy.
\end{abstract}

Keywords: Brain Drain, International Migration, Human Capital, Growth, Economic Methodology and History of Economic Thought

JEL Classifications: B20-B41-F02-F22-H20-I20-I30.

\footnotetext{
\# Department of Economics, University of Bologna, Italy . Marie Curie Training Fellowship at Universitat Autonoma de Barcelona, Spain.

e-mail giannoccolop@,libero.it web page www.dse.unibo.it/giannoccolo
} 


\section{Introduction}

This survey reviews the theoretical and empirical literature on the Brain Drain (BD hereafter). We propose an ideal path that links the first studies (in the 1950s) with the most recent ones. In this development, the BD's literature focuses on different economic and social topics: International Migration, Human Capital, Population, International Commerce, Growth, Low Developing Countries, etc. Furthermore, these BD's studies recall often to national and international debates: the role of the International Institutions and Organizations, the illegal migrations, the Human Rights, the Ethnical discriminations, the different USA's migration policies, the post war problems, the illegal migration from Mexico to the USA, the specific Tax Reforms in USA, the Gorbachev's Age, the collapse of the Soviet block, the Chinese policies, etc.

To write this survey, we used a specific methodology. At first, by using internet research's engines as "Jstor", "ScienceDirect" and "EconLit" we identify a large number of articles that analyse the BD. Subsequently, we integrate these sources with others papers from the references and the quotations contained in the former articles. Using this method, we obtained about 350 articles which treat the BD's phenomenon. Through the complete list of articles would be endless, this review can be used as a systematic study to analyse the theoretical evolutions of the BD from the 1950s to the recent years.

The paper is organized as fellows. First, we analyse the different definitions and the historical roots of the BD. This part shows that the BD is a wide and complex phenomenon. Second, we propose an ideal path to interpret the literature. This part analyses how BD is linked to political and social events, according to the Economy.

\section{The Brain Drain}

The term "Brain Drain" is used as a synonymous of the movement of human capital, where the net flow of expertise is heavily in one direction (Salt 1997). Use of the word 'Brain' pertains to any skill, competency or attribute that is a potential asset. Use of the word 'Drain' implies that this rate of exit is at a greater level than 'normal' or than what might be desired. Linking the two implies that the departure of the most talented at an appreciable rate (Bushnell and Choy 2001). The British Royal Society first coined the expression to describe the outflow of scientists and technologists to the United States and Canada in the 1950s and early 1960s. During the following decades BD was characterized as a North-South, developing-developed country issue (Carrington and Detragiache 1999). In general, the Neoclassical literature agrees that positive technological externalities of immigration arise because of the additional capital that is available to the hosting economy. The theoretical argument goes back to the development of the literature of 50's (Hirschman, Myrdal, Perroux, Wallerstein). These authors enjoyed a revival in the mid-1980's with the birth of the so called New Growth Theory. Starting with several papers by Paul Romer $(1986,1987,1990)$ and Robert Lucas (1988), the immigration of skilled migrants has been regarded as stimulating for the dynamics of economic growth. The possibility that the welfare of those remaining in the LDCs could be reduced by an outflow of educated manpower had been recognized in the literature as well. Work by Grubel \& Scott, Berry \& Soligo and Harry Johnson in the 1960s, concludes that welfare of non-migrants would fall only if the migrants' contribution to national output were greater than their income (or consumption in a static model). For several reasons, the literature believes that the conditions for a BD to be welfare-deteriorating are often verified. Starting from this last considerations, Bhagwati proposed a "Brain Drain Tax". This tax should, from one side, reduce the "free riding" linked to the BD and, from the other side, it should be a kind of "monetary compensation" that the Development countries pay to the LDCs for the "draining of their cultural 
and scientific elites". Around the Bhagwati's proposal we find an interesting debate in the papers of Bhagwati \& Dellafar (1973), Bhagwati (1975, 1976a, 1976b) and Hamada (1977).

In the 1960s and 1970s debates concluded that BD was conditioned by political and economic imbalances in the world system (Portes 1976; Lidgard and Gilson 2001). Furthermore, several studies analyse the role of the International Institutions and Organizations, the coordination of the social and migration policies, the legitimacy of restrictive migration policies (in relation to the human rights' declaration), etc.

Finally, in the 1990s, some authors begin to analyse the circumstances where the Brain Drain becomes 'Brain Gain'. Several theoretical papers examine the impact of migration prospects on human capital formation within a context of uncertainty. The rationale is roughly the following: in a poor economy with an inadequate growth potential, the return of human capital is likely to be low and this would lead to a limited incentive to acquire education, which is the engine of growth. However, the world at large does value education at hence, allowing migration to take place from this economy would increase the educated fraction of its population. Given that only a proportion of the educated residents would emigrate, it could well be that in fine, the average level of education of the remaining population would increase (Beine et alia 2001). The Brain Gain is analysed in several papers: i.e. in models when labour is heterogeneous and when only the most skilled residents emigrate (Mountford 1997, Docquier \& Rapoport 1997), in models with homogenous labour (Stark et alia 1998, Vidal 1998) and in models with imperfect information and return migrations (Stark et alia 1997).

\section{Different definitions of the Brain Drain}

Several definitions of BD are given in the English's dictionaries, on the contrary, in the majority of economics' dictionaries this voice is not considered or, more often, it refers to the definitions of International Migration and Human Capital. The absence of the BD's definition in several edition of an authoritative dictionary like The New Palgrave is significant.

The definitions reported below show that, initially, the authors remark the social, ethical and political aspects more than the economical ones.

(1981)

Brain Drain: The migration of educated and skilled labour from poorer to richer countries. Education skill, which represents investment in human capital, is usually cheaper to acquire in poorer, labourabundant countries, since its provision is usually a labour intensive activity. Those with the skills or education then move to more developed countries where the return to their human capital is higher. Such migration is often encouraged by laws and institutional factors, as most countries look more favourably on immigration by those with skills than those without ${ }^{1}$.

(1982)

The Brain Drain is an expression of British origin commonly used to describe one of the most sensitive areas in the transfer of technology. It refers to skilled professionals who leave their native lands in order to seek more promising opportunities elsewhere ${ }^{2}$.

Brain Drain "International migration of highly qualified persons, e.g. surgeons, physicians, scientists and engineers, from low income countries to more prosperous economies, especially the USA. Differences in salaries and research facilities, together with the over-supply of specialized graduates in less developed countries, has brought about this increase in the human capital stock of advanced countries. See also immigration, migration ${ }^{3}$.

Brain Drain: a pejorative description of the tendency for talent people from poor countries to seek employment in richer ones. Sometimes this migration occurs because, while similar skills are needed in both poor and rich countries, the rich pay more for them. In other cases brain drain occurs because

\footnotetext{
${ }^{1}$ The Dictionary of Modern Economics, edited by D. W. Pearce . (1981) The Macmillan press, London.

${ }^{2}$ Kwok \& Leland (1982).

${ }^{3}$ Donald Rutherford (1992) Dictionary of Economics, edited by Routledge, London.
} 
the technical and economic backwardness of poorer countries means that job opportunities there are limited or non existent. It is also possible that brain drain is encouraged because of tendencies in poorer countries to fill such good jobs as there are on a basis of family connections, political influence, and corruption, while on average richer countries, though subject to some of the same problems, tend to fills posts on a slightly more meritocratic basis ${ }^{4}$.

However, the language around the BD has been altering. In the OECD Report (1987) there are two BD's definitions: Brain exchange and Brain Drain waste.

"Brain exchange implies a two-way flow of expertise between a sending country and a receiving country. Yet, where the net flow is heavily biased in one direction, the terms "brain gain" or "brain drain" is used. A further term, 'brain waste', describes the waste of skills that occurs when highly skilled workers migrate into forms of employment not requiring the application of the skills and experience applied in the former job".

Furthermore, in Johnson \& Regets (1998), the authors introduce a new BD's specification: the Brain Circulation.

\begin{abstract}
"This refers to the cycle of moving abroad to study, then taking a job abroad, and later returning home to take advantage of a good opportunity. The authors believe this form of migration will increase in the future, especially if economic disparities between countries continue to diminish. Such circular migration has been observed amongst Malaysians who had studied in Australia, for example".
\end{abstract}

Moreover, Brain Return is an inherent part of the BD debate. In a significant study of Brain Return, Glaser (1978) shows that the commitment to return to the home country is very strong amongst high-level personnel working or studying abroad. Whilst many stays away longer than they initially planned, they eventually return to their home country. Finally, there is the Brain Gain exposed in the previous paragraph and the Black Brain Drain that we analyse in the next one.

\title{
The Brain Drain "ante litteram"
}

Although the BD appears in the 1950's, It is possible identify in previous studies some anticipations to the BD themes. For example, in the following passage is evident that also in the Mercantilist Age, BD's policies were adopted by Governments.

\section{"Privilege granted to Mr. Guichard for the Cotton-Waste's Manufacture of Saint Quentin" 5}

Pierre Guichard, merchant of our city of Saint Quentin, having opened in our above quoted city a factory of Cotton-Waste and of other articles of cotton and thread, he has done humbly observe that, not having been created ever in our Kingdom a factory of this type, he has been forced to support strong costs for attract workers from foreign Countries. [...] for attract many workers in the aforesaid manufacture, we want that the aforesaid workers foreigners that will have worked for six complete and consecutive years in the said manufacture are advised citizens of the Kingdom and naturalized French [...] and in the case in which they during these six years come to die, we want that their widows and their heirs enter in possession of the goods that they will have acquired or that they received in this Kingdom [...].

(Versailles, February 1671)

Furthermore, Richard Cantillon in the « Essai Sur la Nature du Commerce en General », shows that it is well know the importance of the migration of high skilled workers and their education like part of the wealth of a Nation.

\footnotetext{
${ }^{4}$ John Black A dictionary of Economics, oxford NY 1997

${ }^{5}$ In P. Deyon, Il Mercantilismo, Mursia, Milano 1971. The translation is mine.
} 
Si le Roi de France envoïoit cent mille Sujets à ses frais en Hollande, pour y apprendre la Marine, ils seroient inutiles à leur retour si on n'envoïoit pas plus de Vaisseaux en Mer qu'auparavant. Il est vrai qu'il seroit d'un grand avantage dans un État de faire apprendre aux Sujets, à faire les Manufactures qu'on a coutume de tirer de l'Etranger, \& tous les autres ouvrages qu'on y achete; mais je ne considere à-présent qu'un État par rapport à lui-même ${ }^{6}$.

The BD is strictly linked to the concept of Human Capital (HC hereafter). For this reason, if we would identify the historical roots of the concept of BD, we can not avoid to analyse the historical roots of the concept of HC. For a detailed analysis of the $\mathrm{HC}$ we remand to Kikler (1966). He writes:

[...] the concept of human capital was somewhat prominent in economic thinking until Marshall discarded the notion as "unrealistic". Economists who considered human beings or their skills as capital include such well-know names in the history of economic thought as Petty, Smith, Say, Senior, List, von Thünen, Roscher, Bagehot, Ernst Engel, Sidgwick, Walras and Fisher. [...]

In the same work of Kikler, there are underlined the contributions of the authors above-mentioned.

One of the first attempts to estimate the money value of a human being was made around 1961 by $\mathrm{Sir}$ William Petty. Labour to him was the "father of wealth". It must therefore be included in any estimate of national wealth. He used the notion of human capital in attempts to demonstrate the power of England, the economic effects of migrations, the money value of human life destroyed in war. (Hull, 1899, 589-95) [....] From time to time throughout the history of economic thought, economists have included human beings, or their acquired abilities and skills, as a component of capital. Although some of them attempted to estimate the value of this capital - on both microeconomic and macroeconomic levels - and to employ these estimates for a specific purpose (for example, to estimate the total economic losses resulting from war), others have merely included human beings or their acquired abilities and skills, in their definition of capital and recognized the importance of investment in human capital as a means of increasing the productivity. [...] Although he did not specifically define the term "capital", Adam Smith included in his category of fixed capital the skills and useful abilities of human beings. The skill of a man, he said may be regarded as a machine that has a genuine cost and returns a profit". (Smith, 1937, pp 101, 259-66). Jean Baptiste Say (1821, pp 92-94) asserted likewise that since skills and abilities are acquired at a cost and tend to increase worker productivity they should be regarded as capital. This was also the contention of John Stuart Mill (1909, p 47) and William Roscher (1878 p.151) and at the microeconomic level, Henry Sidgwick (1901, pp. 132-34.). [...] To Friedrich List, skills and acquired abilities of human beings [...] were the most important components of a nation's stock of capital. He asserted that, in both production and distribution, the contribution of this human capital to output must be considered (List ,1928, pp. 108-18). [...] Léon Walras who included all human being in the concept of capital and the value, or price, of these human beings, he said, is determined like that of any other capital good. (Walras 1954 pp. 40, 214-216, 271). [...] Although Alfred Marshall admitted that an estimate of the capital value of a man might be useful and discussed clearly the capitalized-net-earnings approach to human capital evaluation. He disregarded the notion as "unrealistic", since human beings are not marketable (Marshall, 1959, pp. 469-70, 705-6). Human beings are included in Irving Fisher's definition of capital. Capital, he asserted, is a "useful appropriated material object", and since human beings have these characteristics. [Fischer (1897) pp. 201-202; (1927) pp 5, 51-52, 68]

\footnotetext{
${ }^{6}$ If the King of France sent 100,000 of his subjects at his expense into Holland to learn seafaring, they would be of no use on their return if no more vessels were sent to sea than before. It is true that it would be a great advantage to a state to teach its subjects to produce the manufactures which are customarily drawn from abroad, and all the other articles bought there, but I am considering only at present a state in relation to itself. Richard Cantillon, Essai sur la nature du commerce en general, 1755, chapter IX, First part.
} 


\section{The Brain Drain in the scientific articles, a quantitative and qualitative analysis}

\subsection{Brain Drain in USA}

After the Second World War (WWII hereafter), the principal beneficiary of migration flows were the United States of America. Consequently, there are several papers that analyse the consequences of the BD in USA. These studies examine the strong social changes in the US due to the constant flow of emigrates, the new composition of the North-American's population and the contribution given by the cultural elites of the Western Countries. It is significant to note that these themes are discussed not only in scientific debates but also in political and legislative ones. For example, there are studies on the consequences of the American migration's policies on the American society, there are papers that analyse how the federal financing influences the migration of American students and there are studies on the BD of black students and professors which move from their University to the white's ones ( phenomenon called "Black Brain Drain"). In the following paragraphs we analyse deeply all these topics. In the chart 1 and 2 (see appendix) are illustrated the number of the papers that study these topics.

\section{Social and economical effects of the Brain Drain in USA}

In the 1960s sociologists, economists and politicians begin simultaneously to analyse the BD in the US. For example, there are the important works of Grubel \& Scott (1966a, 1966b, 1967 and 1976) that analyse the international migration in the US and the BD phenomenon. These works start an animated debate among economists ${ }^{7}$. The debate is not limited to the US but also analyse the BD in Canada. During the same period, several authors analyse the consequences of massive migration in the American Society and the impact of the BD on the Sciences and Research in the USA ${ }^{8}$. These studies are part of a wide and international debate which proposes to reform the Sciences and the Research by an international coordination of Universities, Governments, International Organizations and Foundations. The conference sponsored by the Council on International Affairs and Cultural (Washington, 1966) is a result of these debates The subject of this conference was: The international Migration of talent and Skills. Furthermore, in the 1968, the American Congress constitutes a committee and a subcommittee with the aim to study the BD from the developing countries $^{9}$. In the 1970 s, there are not many studies on these topics. Differently, in the 1980s some authors begin to analyse newly the BD in USA ${ }^{10}$.

\section{Consequences of American policies on the BD}

The contributions of the previous section, analyse the effect of a massive migration in the USA. Another stream of research analyses how American policies influence migration. For instance, there are the works of Mushkin (1962), Friedman (1973) and Keely (1971). In particular, Keely analyses the effects of the Immigration Act of the 1965 on the demographic characteristics of the USA. Differently, Friedman analyses the effect of this Act on the flow of skilled migrants from LDCs.

\footnotetext{
${ }^{7}$ For example, we have comments by Aitken (1968) to Grubel an Scott articles of 1966 and 1967, and their reply to these comments in Grubel and Scott (1968).

${ }^{8}$ Sims (1966,1970), Ladinsky (1967) [he refers to “migration of elites"], Dale (1968), Porter (1968), Ritterband (1970), Fortney (1970) and Whelan (1974) [he analyse the scientific mobility correlated to the BD].

${ }^{9}$ USA Congress, Committee on government operations, scientific Brain Drain from the developing countries (1968) and USA Congress, Subcommittee: the BD of scientists, engineers and Physicians from the developing countries into the United States (1968). In relation to this committees, there is the study of Library of Congress (1974) entitled: “Brain Drain: A study of the persistent issue of international scientific mobility" elaborated for the sub Committee on National Security Policy and Scientific Developments of the Committee on Foreign Affairs, US house of representatives.

${ }^{10}$ There are the papers of Grenwood (1983) [consequences of massive migration to the poorest and richest countries], Grenwood \& McDowell (1986) [consequences of massive migration to the factors' market in USA], Chiswick (1986a, 1986b), Borjas (1987) [how the increase of personal income available for the migrants is the principal motivation to migrate to the USA], Huang (1988) [an empirical analysis of foreign student BD to the USA] and Kossoudji (1989) [how in USA the migrants are assimilated in the Work's market].
} 
Analogues studies are in the papers of Keely (1975), Bellante (1978), Brandt \& McNamara (1980) [The Brandt Commission] and Fogel (1980). Specifically, Fogel reports the principal themes discussed in a Symposium on "United States Immigration Issues" and he analyses the impact of the new American migration's policies on the BD. In 1986, these debates result in the Immigration Reform and Control Act, which analyses the new problems caused by the massive migration in the USA. Finally, Reynolds \& McCleery (1988) study the role of these policies on the American and Mexican migration and Agarwal \& Yochum (1987) analyse the effect of the Eilberg Act on the immigration. All these studies link BD to the contemporaneous events and to the international debates. For example there are studies on the illegal immigrations, on the BD in the Medical Sector, on the BD and Taxation, on the sexual discriminations and studies that refer to specific historical events ${ }^{11}$.

\section{Brain Drain inside the USA and Black Brain Drain}

The BD is also analysed as an internal and specific problem of the USA. For example, there are some studies that analyse the BD caused by the presence of different levels of taxes and subsidies in the American federal districts. Furthermore, considerable are the works of Murphy (1969) [he analyse the internal BD due to the different federal funds assigned to Research and Development] and the work of Palley (1976) [he analyses the costs and financing funds for the non-resident students]. In the 1990s, some authors resume these themes. Of relevance are the works of Ehrenberg (1992), which analyses the migration of the new Doctorates, and the paper of Arum (1996) which analyse the BD in relationship to private and public schools.

There are several works that analyses the so-called "Black Brain Drain" in the USA. This debate is present in each period analysed, due to the numerous meetings and conferences organized by the Journal of Negro Education. It deserves mention to: "The Higher Education of Negro Americans" at the Howard University and the "Black Brain Drain Columbia Forum" both in the 1967. The Black Brain Drain is also studied in several papers between the 1960s and 1970s. For example there are the works of Harding (1968), Henshel \& Henshel (1969), Hartnett (1970), Mommsen (1973, 1974), Morris (1972) ${ }^{12}$, Bachner (1973) and Lyons (1974). According to similar topics, there is the work of Bryce-Laporte (1972) which remarks the inequalities between white and non-white migrants of the second generations and the fact that these last ones are non sufficient integrated in the American society like the Western migrants. Finally, between the 1980s and the 1990s, the Black BD is studied in the papers of Miller (1981), Dookhan (1981), Elmore \& Blackburn (1983), Pierre \&

\footnotetext{
${ }^{11}$ Regard the illegal migration there are the papers of Agarwal \& Winkler (1985), Wilfred (1986), Hill \& Pearce (1990) [they analyse the incidence of the sanctions versus who employs illegal workers], Penaloza (1994) [he studies the Mexican migrants and their integration in USA] and of Chau (2001) [he analyses the political reforms fixed to prevent the illegal migration]. Regard the Medical sector, there are the works of Last $(1963,1969)$ [both referred to the UK's doctors], Jonas (1965), Gish \& Goofrey (1979) [A reappraisal of the Brain Drain. With special reference to the medical profession], Mejia et alia (1979) [medical sectors and nurses], Mick (1987) and Hellerstein (1988) [ he analyses the different influence between Public and Private Funds on the medical innovations]. Regard the Taxation, there are the work of Espenshade \& Minarik (1987) [they study the demographic effect of the American Tax Reform of the 1986] and the work of Greenwood \& McDowell (1991) [they analyse the differences between USA and Canada ad poles of attractions for the BD]. Regard the sexual discrimination, there are the works of Hochschild (1973), Mejia et alia (1979), Spivak (1981) [French Feminism], Benavot (1989) [migration linked to the gender], Pedraza (1991) [Women and Migration], Vega \& Rumbaut (1991) [ethnical minorities and sexual discriminations] and Scott (1993) [he, analysing the Canada and his citizens, refers also to the specific characteristics of the female migration in Canada]. Regards the contemporary historical events, there are the works of Dittmer (1981) [the strategic triangle (USA, URSS and China)], of McDougall (1982) [Space's Age], Portes \& Stepick (1985) [Cubans and Haitians refugees in USA] and Mills (1986) [international mobility of Russian researchers and scientists in the Gorbachev's Age]. In the 1990s, we furthermore find the works of Stavis (1990) [contradictions of the communist reform in China], Hooks (1990) [Pentagons and Defence's Program], Ma (1993) ["exit and voice"; the returns in China of the exiles policy] and Oberschall (1996) [the passage from Socialism to Markets (China and Hunger)]. About this last argument, there are several papers focused on the countries of the former URSS. Let see the following chapters for furthermore details.

${ }^{12}$ Morris resumes perfectly the debate and the worry for the fact that many black professors and students migrate from black institutions to white ones thanks to better work's time, wages and structures.
} 
Adams (1987), Adams (1990) and Allen (1991). Allen, in particular, affirms the importance of analysing the effective Black Brain Drain in relations to twenty years of studies on this topics. Other authors follow the line of research inaugurated by Allen. There are the works of Weaver et alia (1992), Spear (1993) [He analises the Multiculturalism in the American Universities], Ponder et alia (1994) [African-American Higher Education], Krieg \& Wheelan (1995) [the paper, "A Nation Divided by Its Schools", studies the fundamental problem of the funds for the public schools], there are several works that in the 1997 claim the return of the Black Brain Drain in consequence of the new California's laws that are favourable to some minorities by sacrificing the black ones, and, finally, the work of Lundberg \& Startz (1998) about the persistence of racial inequalities in USA.

\subsection{Brain Drain in the rest of the world}

In the 1970s there are several articles that analyse more generally the BD from the sending countries' point of view. For example, there are the papers of Grubel \& Scott (1966), Enke (1969) and Miracle \& Berry (1970). These first works are focused on the BD from Western Countries. In particular the European ones. Furthermore, in the following years, there are several papers that analyse the BD phenomenon either in the LDCs. In the chart 3, 4 and 5 (in the appendix) are indicated the number of papers devoted to these topics.

\section{Europe}

The BD was debated in Europe since the 1960s. Several conferences and the meetings analyse the European migration ${ }^{13}$. About the BD in Europe, Beijer writes : "For a long time the flow of migrants from Europe to the New World was caused by political, racial, religious, and demographic pressure and differences. The migrants came from all social strata. In the nineteenth century and up to 1914, lords and beggars, adventures and underdogs, gold-diggers and bread-winners moved on a large scale from Europe to North America, Latin America, Oceania and South Africa. The challenge to present times is evident. The modern pattern shows a reversal of the flow: skilled labour and scientific personnel are moving from the less prosperous countries to the four richest nations of the world, and especially the United States".

Several paper written in the 1970 s analyse the BD in Europe ${ }^{14}$. Beijer writes : "In Europe the discussion has been encouraged by the report Emigration of Scientist from the United Kingdom, Royal Society (London 1963). This report is also a reaction to articles and letters in the popular press and the professionals journals, in which it was hypothesized that British scientists and technologists were being attracted to foreign countries (especially the USA) by greater professional and economic opportunities there". Describing the others European States, the same author reports: "For Italy and the smaller European countries, the emigration of scientists is proportionately higher because, in most of these countries, the secondary schools teach English with the other languages and their mother tongue, and the universities an adequate knowledge of the English language is considered a matter of course".

\footnotetext{
${ }^{13}$ For example, there is the "European Population Conference" placed in the Council of Europe. This debate emerges also in the "Communication on movements of intellectuals" analysed in Edding \& Badenhöfer (1966) and in the works of Rhoades (1977) and Beijer (1969). Rhoades analyses the intra-European migration inside the Mediterranean basin. ${ }^{14}$ There are the works of Last (1963, 1969), Christoph (1964), Gerstl \& Perrucci (1965), Wilson, James (1966), Pyatt (1968), Johnson (1968), Yates (1968), Uselding (1970), Balacs and Gordon (1975) and Partington (1975). In all these works there is a reference to the BD in UK. Furthermore, there is the article of Blazer (1967), in which is anticipated the relationship between Taxation and $\mathrm{BD}$ and the consequences of the BD on the financial resources of England, there is the work of Brogan (1968) which analyses the Research and the University in Europe, there is the work of Schultz (1968) on the Western Germany's University, finally, there is the work of Bhagwati et alia (1984) [West German's system of immigration].
} 
In the 1980s there are few works that analyse the BD in Europe. These topics enjoy a revival in the1990s. In particular, there are studies on the Irish migration, the unification of the Germany and the BD received from Eastern Europe ${ }^{15}$.

\section{Canada}

In the 1960s, there are several works that analyse the BD in and from Canada ${ }^{16}$. As for the analises on the BD in USA, also in this case the paper of Scott \& Grubel starts an interesting debate. Furthermore, it is interesting to note that the BD was not always from Canada to the USA, but from others countries to Canada and, in some particular occasions as the Vietnam's war, the constant migratory flow from Canada to USA is compensated by an equivalent one from the USA. Either in the $1970 \mathrm{~s}$, the $1980 \mathrm{~s}$ and in the 1990 s there are several works devoted to study the BD in Canada ${ }^{17}$. For this reason, it is also possible affirm that there exist an authentic Canadian schools on these topics.

\section{LDCs and others}

Several are the papers that analyse the BD in the LDCs. There are paper that analyse the BD in the Central and South America ${ }^{18}$ and in Asia ${ }^{19}$. For what regards Africa, there are some recent contributions $^{20}$. Most of these developed in the 1990s and analyse the state of the University and of the Research in Africa. Also, there are several studies on the BD in URSS $^{21}$ and in other countries ${ }^{22}$.

${ }^{15}$ Regard the Irish migration, there are the works of O'Rourke (1992), which analyses the motivation for the Irish emigrants to migrate, and O'Hearn (1994) which analyses the Irish industrial History. Regard the unification of the Germany, there are the works of Rhode (1991) which analyses the BD form Eastern Europe to Western Europe, of Jurgens, Klinzing \& Turner (1993) [BD form Eastern Germany to Western Germany] and others articles related to the ex URSS. Regards the Eastern Europe, there are the papers of Wolburg (1996, 1997), Wolburg \& Wolter (1997) [BD inside the EU], Salt et alia (1999), Bauer \& Zimmermann (1999), Straubhaar \& Wolburg (1999), Dauderstädt, (2001) and Salt (2001).

${ }^{16}$ In the 1960s there are the works of Johnson (1965a, 1965b, 1965c), Triantis (1965), Musgrave (1968) [He analyse the "Carter report" and the influences of the taxation on the BD], Scott \& Grubel (1969) and Trueman (1969).

${ }^{17}$ In the 1970s there are the works of Comay (1970), Holmes (1974), Devoretz \& Maki $(1975,1983)$, Boyd (1976) and the book of Grubel \& Scott (1977) entitled "The Brain Drain". In the 1980s, there are the works of Boadway \& Flatters (1982)[taxation and Canadian BD], of Markusen (1988) and of Kesselman (1988). Finally, in the 1990s there is the work of Greenwood \& McDowell (1991) which analyses the difference between USA and Canada like "BD attraction's poles". Furthermore there are the works of Lipset (1993), Scott (1993), Akbar \& Devoretz (1993) and Helliwell (1999).

${ }^{18}$ There are the papers of Loomba, Turban \& Cohen (1968), Hall (1973) [He compares the population's growth in USA and in Latin America] and Ayres (1975) concerning the Latin America in general. There is the paper of Oteiza (1965), dedicated to Argentina. There is the work of Sahota (1968) which analises the BD internal the Brazil. Furthermore, several studies analyse the consequences of massive migrations from Mexico to USA. There are the works of Beijer (1966), Reynolds \& McCleery (1988), Wenez \& Ronfeldt (1991) and Penaloza (1994). There is the work of Funkhouser (1982) [Nicaragua]. Finally, Portes \& Stepick (1985) study the Haitian and Cuban refugees in USA.

${ }^{19}$ There are the works of Kroef (1968) and Baldwin (1970) which refer to the Asia in general. Others works analyse in depth the Pakistan: Wilcox (1968) [internal BD] and Liesch (1968) [the University in Pakistan]. There is work of Turkcan (1974) that regards the Turkey. There is the work of Goldfarb et alia (1984) regard the Philippine. There is the paper of Malek (1981) that analyse the Iran case. Several studies regards Taiwan: Appleton (1970), Ho (1975) and, more recently, Wei-cheng Wang (1995)[he analyse if, in Taiwan, there is BD or Brain Gain thanks the positive externalities due to the international migration from Taiwan to other countries]. Regards Singapore there are the works of Quah (1989) [ BD and medical sector in Singapore] and Beng (1990). Concerning the political and migration consequences due to the return of Hong Kong to the China, we find the works of Cheng (1990) and Skeldon (1990). Several works analyse the BD in India: Cassen (1976), Vicziany (1982), [Indian population] Lakshmi and Bean (1976) [Indian University], Weiner (1982) [Indian migrations on the Persian Gulf], Madhavan (1985), Lewis (1991) [the Research in India], Radhakrishnan (1993) and MacNeil (1993). About the China there are only recent works: Bakken (1988), Hayhoe (1988) [Reform of the Chinese University], Ma (1993) [“exit and voice" and return of the exiles' policies in China] and Zhiduan (1992) [BD in China]. Finally, the Sri Lanka's University is studied by Matthews (1995) and the BD in Japan is studied in the works of Dore (1972) [Japan and the importance of the tradition on the Education policies] and Rostow (1985) [Japanese or American commercial leadership for the Pacific Zone].

${ }^{20}$ We find the works of McCain $(1979,1980)$ [Ghana], Udofia (1984) [the multinationals in Africa], Wood (1989) [apartheid in South Africa and BD quotes like one of the social consequences], Shermann (1990) [Research and Universities in the "modern Africa"], Nhundu (1992) (Zimbabwe), Ehie \& Smith (1994) [Technological Research in 


\title{
2.3 International Organizations, Population and Research
}

After the WWII, the role of the international organizations increases and several scientists and politicians try to find a common language and new international relationships. In this scenario, there are several studies about the role of the International Organizations to limit the negative externalities caused by massive migrations and the consequent BD. Furthermore, other studies analyse the consequences of big migratory flows on the population. Finally, recognising the importance of the Education and the Research in a national and international environment, the authors analyse how to coordinate the international research, how to limit the BD phenomenon, and how to reform the Universities and the Research's structures considered obsolete and inadequate. Chart 6 and 7 (in the appendix) shows the number of papers that study these topics.

\section{The International Institutions}

In the 1960s and in the 1970s there are many works that analyse how the International Organizations must manage the economical and social consequences of international migrations. Some authors analyse the links between civil rights and freedom to migrate, the links between the Labour and the International Relationship, the future international collaborations and their role to influence the growth's rate of a Nation and the relation North-South of the World ${ }^{23}$. In the 1980s, also in reference to the Universal Declaration of Human Right, these topics are newly analysed ${ }^{24}$. Moreover, In the 1991 we find an analysis done for the ONU about the Social Situation in Africa. In this analysis, there is also some mentions to the BD's question. In the "Recommendations" deliberated in the International Conference on Population of the 1984 there are references to the BD's problem.

\author{
International migration \\ (a) General guidelines for formulating international migration policies \\ Recommendation 46 \\ In formulating policies on international migration, Governments of receiving countries should take into \\ account not only their own country's economic and social needs but also the well-being of the migrants \\ concerned and their families and the demographic implications of migration. Governments of countries \\ of origin concerned with the continuing outflow of skilled workers and professionals should seek to
}

\begin{abstract}
Nigeria], Laitin D. (1994) [University in Ghana] Hoffman (1995) [concerning the destruction of the Sub Sahara's Research], Zack-Williams (1997) [African Diaspora in UK], Abrokwaa (1999) [Strategies for the Development of the Africa; role of the USA and of the Europe].

${ }^{21}$ Regarding the ex URSS, we find the works of Mills (1986) [he studies the different international mobility for the scientists in the Gorbachev's Age.], Hogan (1991), Svejnar (1991) [both refer to the economic Reforms in the Nations of the ex URSS], Coleman (1993) [about the different demographic characteristic of Eastern Europe, Western Europe and ex URSS] and Oberschall (1996) [he analyse the passage from Socialism to Markets for the China and Unger].

${ }^{22}$ There are the work of Ritterband (1969) [on Israel],the work of Suleiman (1973), which analises the changes on the society due to the BD of Arabs in Palestine and Israel, and the work of Palfreeman (1974) which remarks, in relations to the Australia, the differences between the white migrants and the non-white ones.

${ }^{23}$ Regard the role of the International Organizations, there are the works of Cox $(1968,1979)$, Revelle (1968), Sherman (1968), Bell (1971), Keohane \& Nye (1974), Pastor (1974) and Meron (1976). They refer essentially to the UNESCO, ILO (International Labour Organization), IAEA (international Atomic Energy Agency) and to the ONU. Bell analises, instead, the international role of the Ford Foundation. Regard the civil rights, there are the papers of Nett (1971) and of Field (1971). Afterward, we find the works of Hirschman \& Nelson (1976) and of Hirschman (1978) which analyse the BD by using the "exit and voice" methodology. Regard the Labour and the International Relationship, there are the works of Cox (1971) and Nye \& Keohane (1971). Regard the Growth, there are the works of De Seynes (1972), Ruggie, Sathyamurthy (1973) and "The Cocoyoc Declaration" of 1975. Regard the relation North-South of the World, there is the work of Diaz-Alejandro (1975).

${ }^{24}$ There are, for example, Streeten (1980) [Basic needs and human rights], Weston (1981) [He refers explicitly to the Universal Declaration of Human Right], Whelan (1981) [He refers to the themes of Citizenship and Right to migrate], Hantke (1983) [He analises the Discrimination and the protection of the minorities], Nafziger (1983) [He analises the role of the international laws on influence the migration's flows], Hannun (1987) [He refers to the "Strasbourg Declaration on the Right to leave and Return" of the 1986] and Said (1991) [He analyses themes like Identity and migration's Freedom].
\end{abstract}


retain those workers as well as encourage their return through, inter alia, the promotion of an economic favourable to their expansion of employment opportunities. To redress the existing imbalance of skills, Governments should try to identify alternative skills resources. Government should formulate national and international measures to avoid the brain drain from developing countries and to obviate its adverse effects. Governments are invited to conduct, inter alia, consultations or negotiations, on either bilateral or multilateral basis, with the support, upon request, of competent international organization.

In the 1995 Vagts analyses the proposal of an "expatriation tax" and the eventuality that this tax can violate Human Rights. The suggestions to introduce compensations for the negative externalities of the BD are numerous and often refer directly to the Bhagwati's proposal.

Finally, in the 1980s and 1990s, some authors analyse the delicate problem of illegal migration. For example, we have the papers of Lundahl (1985), Wilfred (1986) and Hill \& Pearce (1990). In these works emerges the exigency of an international coordination to avoid this problem. In the next decade, we also find the work of Chau (2001) on the immigration's policies reform and on illegal immigration.

\section{Population and BD}

Several articles analyse the consequences of a free migration on the population. For example, there are studies and the meeting that analyse the "Family program", the "World Population Plan of action" and others similar themes ${ }^{25}$.

During the 1970s, there are the "European Population Conference" in Strasbourg (1972), the "Meeting of the population Association" (1972 and 1974), the "World Population Plan of action" (1974 and 1975) and the "Population in the World Employment Conference" in the 1976. All these meetings and conferences analyse the worldwide population and the changes due to migrations. Of relevance are also other two conferences: United Nations International Conference on Population, $3^{\text {rd }}$ edition in Bucharest $(1974)$ and the $4^{\text {th }}$ edition in Mexico city (1984). As a result of these conferences were several studies on the consequences of a quick growth of the population and the so called "International Migration Guides", which analyses the BD's problems. These topics were also studied in the "Program of Action of the 1994 International Conference on Population and Development".

\section{International coordination of the Research and University}

Analysing the role of the International institutions, some papers study the importance of a wide coordination of the Research and among Universities. The more is the consciousness of the important role of the Education as national and international resource, the more are the proposals to coordinate internationally the Research. In the 1960s, some authors note the backwardness of several scientific Research's structures in HDCs and in LDCs and remark the necessity to stop the BD's phenomenon. Other scientists also analyse the condition of Research in Western Europe and in Asia ${ }^{26}$. In the 1970s the debate is enlarged to the role of the Institutions on the Education's

\footnotetext{
${ }^{25}$ In the 1960s there are the articles of Edding \& Bodenhofer (1966), the book of Brass (1969), entitled Population Growth and the Brain Drain and the work of Sauvy (1966). In the 1970s there are the works of Hall (1973) [he compares the population's growth between USA and Latin America], Brass (1974), Watson (1975), Berelson (1975, 1976), Cassen (1976) [he refers to the India] and Kitagawa (1977). In the 1980s there are several studies focused on the links between population and migration (and so BD). For example, we find the works of Miro \& Potter (1980) and the Population Brief of 1980 [Latin America]. Furthermore, there are the works of Hobcraft, Menken \& Preston (1982), Vicziany (1982) [India], King (1983) [he studies the migration from the LDCs and its social consequences for these ones], Kuper (1983), Tabah (1984), McNicoll (1984) [he analises the consequences of a quick population's growth], Bernard (1986), Kearney (1986), Caldwell, Caldwell \& Caldwell (1987), Wood (1989) [he, analysing the social aspects of the apartheid in South Africa, quotes the BD as one of these consequences] and Scheffel (1990).

${ }^{26}$ Regards the Research in the LDCs, there are the works of Warren (1968), Fores (1969) and Russet (1969). Regards the Western Europe, there are the papers of Brogan (1968) and Schultz (1968). This last one studies the Western Germany. Regards the Asia, There are the works of Liesch (1968) about the Pakistan, Dore (1972) about the Japan and the importance of the tradition on the Education, and of Lakshmi \& Bean (1976) about the India.
} 
policies ${ }^{27}$. In the 1980s and 1990s this debate regard either general topics either specific contexts as the Research in Asia and in Africa ${ }^{28}$. Furthermore, within the Institutions founded in these years, there is the UNITAR [United Nations Institute for training and research]. Finally, in the "Program of Action of the 1994 International Conference on Population and Development" it is possible identify some crucial points of the debates on these topics.

\section{Chapters XI Population, Development and education}

$11.4[\ldots]$ Inadequacies in and discrepancies between the educational system and the production system can lead to unemployment and underemployment, a devaluing of qualifications and, in some cases the exodus of qualified people from rural to urban areas and to 'Brain Drain'. It is therefore essential to promote harmonious development of educational system is and economic and social system conducive to sustainable development.

\subsection{The Brain Drain in the Economics Models}

In this section, analysing the different models used to study the BD, we recreate the ideal path that the BD's authors crossed. First, scientists analyse the consequences of the BD on Welfare. Second, they recognized the crucial connection between Education and Technology and, hence, the importance of an analysis of Human Capital as a principal element of the National Account. Third, they studied the impact of the BD on the International Commerce and on the taxation . They also analysed the possibility to introduce compensating mechanisms as the Bhagwati's tax. Fourth, they studied how the BD decrease the Wealth and the potential Growth of the LDCs. Fifth, some authors analysed the BD stressing the importance of individual's characteristics on the migration's decision. These studies are within a more broad attempt to micro-found the Economic models. Finally, during the 1990s, some authors begin to introduce the possibility of positive externalities due to the BD. This last branch of the literature is labelled Brain Gain. Charts 8 and 9 (in the appendix) shows rated the number of papers devoted to these topics.

\section{Brain Drain and Welfare}

First studies on the BD phenomenon analyse its consequences on the Welfare of the countries involved in this flow of people. Some authors compute the social costs due to the migration. These costs entered in the National Account as an important voice. Several scientists point out the necessity of accounting these social costs. For example, research by Schultz analyses the notion of "human capital". Successively, at the end of 1960s, several articles analysed the consequences of BD on Welfare. In the 1970s there are several studies and during this period we have the important contributes of Bhagwati ${ }^{29}$. Finally, in the ONU's General Assembly of the 1976, the "Welfare effects of BD" is discussed.

\footnotetext{
27 There are the works of Stone (1972) [on the social consequences of the education], Streeten (1974) [limit of development research], Simon \& Pilarski (1979) [on the consequences of the population's growth on the amount of education received] and Jordan (1976).

${ }^{28}$ We find the works of Tinto (1982) [students' problems], Mills (1986) [changes on the mobility of the researchers in the Gorbacev's Age], Hartnett (1987) [BD in the Arts and in the Sciences], Woodhall (1987) [financing student flows], Huntington (1988) [Reforms for the Political Science], Bird \& Allen (1989), Geiger (1990) [research in University], Levin \& Stephan (1991) [studies about the "productivity of the Research"], Ehrenberg (1992) [the flow of the new Doctorates] and Arum (1996) [private and public schools in USA]. Regard the Asia, there are the works of Bakken (1988) and of Hayhoe (1988).[both are about the reform of the University in China], the work of Lewis (1991) [India] and the work of Matthews (1995) [Sri Lanka]. Regard the Africa, there are the works of Shermann (1990) [the University in the "modern Africa"], Nhundu (1992) [Zimbabwe and educational policies] , Laitin (1994) [Ghana' University], Ehie \& Smith (1994) [Technological Research in Niger] and Hoffman (1995) [destruction of the research in the Africa Sub Saharan].

${ }^{29}$ There are the works of Schultz (1959) [Investment in man: an economist's view ] and Schultz (1960) [Capital Formation by Education], Sjaastad (1962), Weisbrad (1964) [positive externalities of the public Education], Bowman \& Myers (1967), Bodenhofer (1967), Galtung (1967) [scientific colonialism], Berry \& Soligo (1969) [they analyse the "Welfare aspects" of the international migration], Watanabe (1969) [he analyses the BD from LDCs to the Western
} 


\section{Brain Drain and Education}

Recognized the crucial role of the BD on the Nations' Welfare, some researchers investigate the relationships between $\mathrm{BD}$ and Education. The Education is not only an important element of the Welfare but it is also a key factor of Innovation, Technology changes, development and Growth. In this context, the effects of the BD on Education affect the Development. In the 1960s, 1970s and 1980 s there are several authors that analyse these topics ${ }^{30}$.

\section{Brain Drain and International Commerce}

Many authors tested how the BD is a key element in the international commerce because of its influence on some crucial production's factors. These arguments were anticipated by the work of Blejer (1978). In the $1980 \mathrm{~s}$ and $1990 \mathrm{~s}$, there are several articles devoted to these topics ${ }^{31}$. In particular, Rauch (1991) stresses the necessity to reconcile the themes of the Commerce with the ones of Migrations.

\section{Brain Drain and taxation}

Many authors analyse the connections between the BD and taxations. For example, the work by Blazer (1967) analyses the consequences of the BD on the English taxation, and the work of Musgrave (1968) links the taxation with the Canadian BD. These topics are studied by Bhagwati and by other authors that followed a similar approach of the subject ${ }^{32}$. Finally, it is important to remark the "Bellagio Conference on the Brain Drain and Income Taxation", in Italy from 15 to 19 February 1975, where the scientist discussed several of these arguments.

\section{Brain Drain and Growth}

In the 1970s, some authors analyse the connections between BD and development. One of the important result of these studies is that the BD from the LDCs can explain the development of these

Countries] and Johnson (1969a, 1969b) [he analyses how the Welfare of those remaining at home changes in presence of BD and, in the second work, the circulation of the human capital]. In the 1970s, there are the works of Baldwin (1970), Scott (1970) [he analyses the opportunity to apply the human-capital's approach to study the BD's phenomenon], Romans (1974), Rodriguez (1975) Usher (1977), Glaser (1978) and Gmelch (1980). Regard Bhagwati, there are several works: Bhagwati \& Hamada (1974), Bhagwati et alia (1975), Bhagwati \& Rodriguez (1975), Bhagwati \& Wan (1979).

${ }^{30}$ In 1960s and 1970s there are the works of Bodenhofer (1967), Patinkin (1968), Johnson (1972) [he analises the thecnological gap between Western Countries and LDCs ones], Thompson (1974), Streeten (1974) [he analises the connection between Technology and Development inside BD's topics], Haas (1975) [he studies the necessity to coordinate the Technology in an International framework], Johnson (1975) and Rodriquez (1975). In the 1980s, there are the works of Reubens (1983) [he presents models of the international migration from LDCs to Western Countries], Blomqvist (1986) [he studies the economical returns of the Education and the consequences on the Welfare of the international migration], Kindleberg (1986) [he studies the economical returns of the Education and the consequences on the Welfare of the international migration], Wong (1986) [an economic analysis of the international migration], Djajic (1989) [he studies the economical consequences of quantitative and qualitative restrictions to the international migration], Bhagwati (1991) [connection between Education and Welfare], Glaz'ev \& Malkov (1992), Wong \& Kee Yip (1999) and Beine et alia (2001).

31 There are the works of Corden (1984) [he studies the contributes of H Johnson], Ethier (1985) [international trade and labour migration], Rostow (1985) [ Japanese or American commercial leadership in the Pacific's Area ], Rauch (1991), Gould (1994) [he analises the immigrants' consumptions in theirs native countries and the consequences on the commerce] and Ishikawa (1996) [Scale's Economies of the productive factors and migration].

${ }^{32}$ There are the works of Bhagwati \& Dellafar, (1973) [BD and Income Taxation], Bhagwati \& Patrington ed. (1976) [ in which there is the proposal to introduce an international taxation to recompense the LDCs for the BD], Krugman \& Bhagwati (1976) [in the book edited by Bhagwati and entitled: The Brain Drain and Taxation] and Bhagwati (1979) [ links between BD, taxes and Ethics]. McCulloch \& Yellen (1975) [taxes and BD] and the book of Hamada (1977) Taxing the Brain Drain: a global point of view The new international order, edited by Bhagwati. Successively, these topics are resumed in the works of Boadway \& Flatters (1982) [how the taxation can influence the Canadian BD], Minarik (1987) [how the taxation can influence the Canadian BD], Kay (1990), Wilson (1992) [he studies the "optimal Income tax"], Chang (1995) [how the taxation increase the BD's phenomenon], Vagts (1995) [he studies the proposal of an "expatriation tax" and if this tax violates the Human Rights] and Bucovetsky (2003). 
countries. In the 1980 s and in the 1990 s several studies analyse these topics ${ }^{33}$. These works analyse the "long run" effects of the migration and of the Education's policies. Human Capital is treated as a important productive factor which is subject to the economies of Scale: it is subject to "Learning by Doing" and to different levels of obsolescence. These topics are not only analysed in academic works but also in Institutional organizations. For example there is the "Conference on Trade and Development-migration of skilled workers" organized by the ONU.

\section{Brain Drain and Income}

Within a general Micro-foundation of the Economics, some BD models start to investigate the personal motivation to migrate. These studies remark the importance of Income as key factor in the decisions to migrate. In the $1990 \mathrm{~s}$, several studies that analyse the connections between migration and wages' differentials, the "Optimal income taxation and international Personal mobility" and several others micro-economics themes linked BD to the motivations to migrate ${ }^{34}$.

\section{Brain Drain and Brand Gain}

In the 1990s some authors analyse the circumstances that lead to positive externalities for the sending countries. These studies found that BD should be defined as Brain Gain ${ }^{35}$.

\subsection{Miscellaneous and Brain Drain's Books}

Some authors, in the contest of the world economic history, mentioned the BD's phenomenon due to the different migratory flows. Other articles analyse the BD together with other themes: models of international productivity, models of the decisions' analysis, changes in Age of Marriage in the UK, International Migration under Asymmetric Information, R\&D and Corruption, etc ${ }^{36}$.

\footnotetext{
${ }^{33}$ In the 1970s there are the works of Pavitt (1973), Robinson (1974), Epstein (1974), Greenwood (1975) [he anticipates the important role of the technological competition and its consequences on the development], Ayres (1975) [he analyses the Latin America], Mc Culloch \& Yellen (1977) and Petersen (1978). In the 1980s Kwok \& Leland (1982) introduce a new model of the BD. This work starts an important debate how evidence the papers of Katz \& Stark (1984) and, in answer to these ones, the new works of Kwok \& Leland (1984). Furthermore, there are the papers of Harbeger \& Wall (1984) [they studies the figure of H. Johnson, in his studies on the Development's themes], Caves (1984), Corden (1984) [he analyses the contributes of H. Johnson on the International Commerce's Theory] and Djajic (1985) [he studies the Human Capital and how it can influence the Growth of a county]. In the 1990s there are the works of Chen \& Su (1995), Romer (1986) [Long run growth ], Miyagiwa (1988) [Human capital and Economic Growth], Chiswick C. (1989) [consequences of the migration of Human Capital on who remains at home], Benavot (1989) [Education, Gender and Growth], Reichlin \& Rustichini (1998), Becker et alia (1990) [Human capital, Fertility and Growth], Miyagiwa (1991) [Scale's economies for the education and the BD problem] and Wong \& Yip (1999).

${ }^{34}$ Regard the wage's differentials, there are the works of Davies \& Wooton (1992) and Engerman \& Jones (1997). Regard the income's taxation, there is the paper of Wilson (1992). Regard different individual's motivations to migrate, there are the works of Bernabou (1993), Acemoglu (1996), Carrington et alia (1996) and Davenport (2004). Furthermore, there are several themes analysed: the migration linked to the endogenous moving costs, the themes of Efficiency and Equity in the relationship between HDCs and LDCs [Bardhan (1996)], the influence of the income on the high education [Heckman et alia (1996)], the debate about the private and public schools [Arum (1996)], the Income and its implication on the convergence in the industrial development of the countries [ Goodfriend \& McDermott (1988)], and, finally, the Urban Growth [ Black \& Henderson (1999)].

${ }^{35}$ There are the articles of Abu-Rashed \& Slottje (1991), Wei-cheng Wang (1995) [he analises the migrations in Taiwan and if it is opportune define them BD or Brain Gain], Stark, Helmenstein \& Prskawetz (1997, 1998), Mountford (1997), Straubhaarn \& Wolburg (1999) [he analises the migration from Eastern Europe to Germany], Straubhaar (2000), Stark \& Wang (2002) and Stark (2004).

${ }^{36}$ Regard the historical analysis, there are the works of Heaton (1965), Crouzet (1971) [Europe's History],van de Walle (1974) [History and Demography], Rostow (1985) [Stylised historical analysis of the Worlds Economy until the 1945], Heilbron \& Kevles (1988) [Science and technology in the USA History Textbooks] and Lund (1998) [Industrial Strategy in the History (UK)]. Furthermore, there are the articles of Etzioni (1966) [guidance of science], Nelson (1968) [Models of international productivity], Dror (1970) [Models of the decisions' analysis], Farid (1974) [childbearing], Crafts \& Ireland (1976) [changes in Age of Marriage in UK], Morauta (1979) [New Guinea], Fahim \& Helmer (1980) [LDCs], Katz \& Stark (1987) [International Migration under Asymmetric Information], Shore (1992) [anthropology], Khanna \& Iansiti (1997) [Firm Asymmetries and sequential R\&D] and Ades \& Di Tella (1997) R\&D and Corruption.
} 
Several books analyse the BD phenomenon. In the 1960s there are the works by Becker (1964) [about the Human Capital and the Education], by Adams (1968) [general topics on the BD] and by Brass (1969) [population, Growth and BD]. In the 1970s there are several books by Bhagwati and others authors". Finally we have the work by Bhagwati \& Wilson (1989) "Income Taxation and International Mobility".

\section{Conclusion}

The objective of this survey is to propose an ideal path that connects the first studies on the BD in the 1950s with the most recent papers. In the first part of the paper we analysed deeply the BD and its main definitions. In the second part we studied the historical roots of the BD. In the third part we analysed the "geography" of the BD and the several economic models. Finally, it is possible propose the ideal path of the BD literature. To better understand the evolution of the $\mathrm{BD}$, it is necessary to use the evolution of the HC literature. In what follow we expose this path.

When the HC literature analyses the social aspect of Education, studies on the BD analyse the impact of the high skilled migration on the Social Welfare. The first countries analysed are the West Europe's ones, USA and the Canada. Several studies analyse the BD in the UK, which is the country where BD phenomenon appears in the first time. The results of these studies are the following: the main motivations to migrate were political and social; the effects of these migrations are bad either for welfare or for the social structure of the sending countries: the solution is to create and fortify the role of the International Organizations and Institutions on the management of the migration flows.

When the literature recognizes the importance of the $\mathrm{HC}$ in the National Account and the fact that it is a very peculiar productive factor, then these studies analyse the impact of the $\mathrm{BD}$ on the international commerce, on the Labour market, on the provision of public goods and on the taxes. These studies analyse mainly LDCs and emerging countries. The results of these studies are the following: the main motivation to migrate was the fact that the Labour markets are incomplete and not able to employ high skilled workers: the effects of these migrations are bad for the development of the sending countries; in the short run the tax system of the LDCs country fails: the solution is to fortify the coordination between LDCs and HDCs and to introduce BD taxes to compensate the negative externalities (Bhagwati's tax).

When the literature recognizes the importance of the $\mathrm{HC}$ as main factor of the Growth, then these studies analyse the impact of the BD on the Growth and on its Macroeconomic implications. These studies analyse mainly LDCs but several works analyse also the HDCs. The results of these studies are the following: the main motivation to migrate was the more productivity (and higher income) of the skilled workers in the HDCs; the effects of these migrations are bad for the Growth of the sending countries; in the long run increase the divergence between the HDCs and LDCs: the solution is to create incentives for the workers to come back by increasing the opportunity to work in the LDCs and by decreasing the productivity's gap.

When the literature analyses the role of the HC in the IT, then these studies analyse the impact of the BD on the Innovation, Technology and on its Microeconomic implications. These studies analyse either LDCs or HDCs. The results of these studies are the following: the main motivation to migrate are linked to individual aspects (income, vote with their feet, social, private, etc): the effects on the Growth of these migrations are not certain, they can be Bad or Good (Brain Gain). They are bad for the Growth of the sending countries as they increase the divergence between the HDCs and

\footnotetext{
${ }^{37}$ There are the work of Bhagwati (1976), entitled "The Brain Drain and taxation" in which there are most of the articles quoted in the previous chapters, Bhagwati \& Patrington (1976) entitles "Taxing the Brain Drain: A proposal", Bhagwati (1976) "In The Brain Drain and Taxation, vol 2. Theory and Empirical Analysis", Hamada (1977) "Taxing the Brain Drain: a global point of view The new international order", Grubel \& Scott (1977) and Glaser (1978) "The Brain Drain: Emigration and Return".
} 
LDCs in the long run: the solution is to create individual incentives for workers to come back, an international coordination and, when it is possible, to create the conditions to have a Brain Gain.

The table below sums up these conclusions.

\begin{tabular}{|c|c|c|c|c|}
\hline $\begin{array}{c}\text { Human Capital } \\
\text { (HC) and } \\
\text { Education }\end{array}$ & $\begin{array}{l}\text { Social Aspects of } \\
\text { the Education }\end{array}$ & $\begin{array}{l}\text { Education implies } \mathrm{HC} \\
\mathrm{HC} \text { is a very peculiar } \\
\text { productive factor }\end{array}$ & $\begin{array}{l}\mathrm{HC} \text { is an important } \\
\text { component of the } \\
\text { Economic Growth }\end{array}$ & $\begin{array}{c}\text { HC and its effect on } \\
\text { technology and } \\
\text { Progress }\end{array}$ \\
\hline \multicolumn{5}{|c|}{ Brain Drain's Studies } \\
\hline Topics & Social Welfare & $\begin{array}{l}\text { International Commerce - } \\
\text { Labour Market - Public } \\
\text { Goods - Taxes }\end{array}$ & $\begin{array}{l}\text { HC and Growth (LDCs } \\
\text { and HDCs) + MACRO } \\
\text { aspects }\end{array}$ & $\begin{array}{c}\text { Innovation, } \\
\text { Technology and } \\
\text { Growth }+ \text { MICRO } \\
\text { aspects }\end{array}$ \\
\hline Countries & $\begin{array}{l}\text { UK, West Europe, } \\
\text { USA and Canada }\end{array}$ & LDCs and HDCs (few) & $\begin{array}{c}\text { LDCs } \\
\text { and emerging countries }\end{array}$ & HDCs and LDCs \\
\hline $\begin{array}{l}\text { Motivation to } \\
\text { Migrate }\end{array}$ & Political and Social & $\begin{array}{l}\text { Market incomplete or } \\
\text { inadequate to employ } \\
\text { skilled workers }\end{array}$ & $\begin{array}{l}\text { More productivity (and } \\
\text { so income) of the } \\
\text { skilled workers in the } \\
\text { HDCs }\end{array}$ & $\begin{array}{c}\text { Individual } \\
\text { motivation (income, } \\
\text { vote with their feet, } \\
\text { social, etc) }\end{array}$ \\
\hline $\begin{array}{c}\text { Effects and } \\
\text { Consequences }\end{array}$ & $\begin{array}{l}\text { Bad effect on the } \\
\text { welfare, on the } \\
\text { social structure and } \\
\text { on the population }\end{array}$ & $\begin{array}{l}\text { Bad effects on the economy } \\
\text { and on the development } \\
\text { (Short Run effect on the } \\
\text { taxes, on the } \\
\text { unemployment, etc ) }\end{array}$ & $\begin{array}{l}\text { Bad Effects on the } \\
\text { economy and on the } \\
\text { Growth (Long Run } \\
\text { effects, increase of the } \\
\text { divergences between } \\
\text { LDCs and HDCs) }\end{array}$ & $\begin{array}{c}\text { Bad Effects and } \\
\text { Good Effects (Brain } \\
\text { Gain) }\end{array}$ \\
\hline Solutions & $\begin{array}{l}\text { International } \\
\text { Organizations and } \\
\text { Institutions }\end{array}$ & $\begin{array}{l}\text { Coordination among States } \\
\text { and } \mathrm{BD} \text { taxes to compensate } \\
\text { the externalities }\end{array}$ & $\begin{array}{l}\text { Incentives to coming } \\
\text { back and increase the } \\
\text { opportunity to work in } \\
\text { the LDCs }\end{array}$ & $\begin{array}{c}\text { Individual } \\
\text { Incentives } \\
\text { Implement the } \\
\text { conditions to have } \\
\text { Brain Gain }\end{array}$ \\
\hline
\end{tabular}




\section{Appendix}

BD and USA - Figure 1

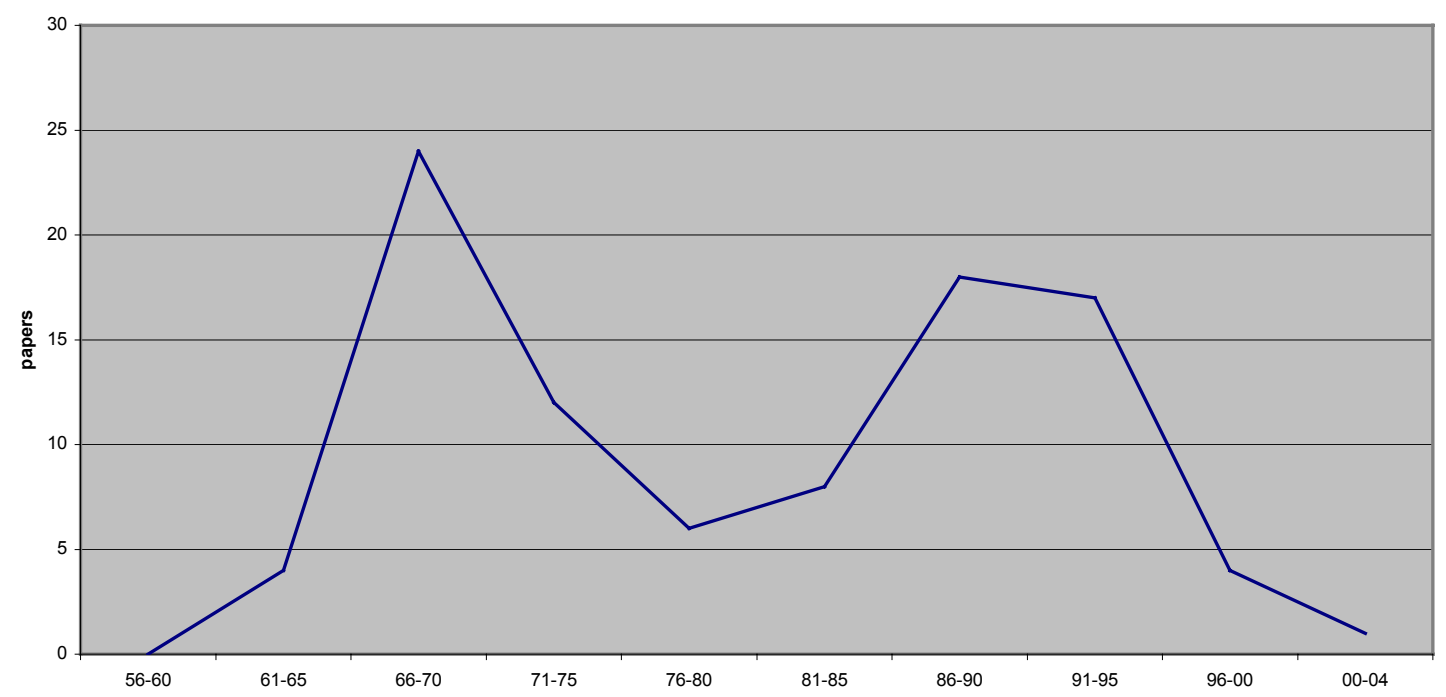

$\mathrm{BD}$ and USA - Figure 2

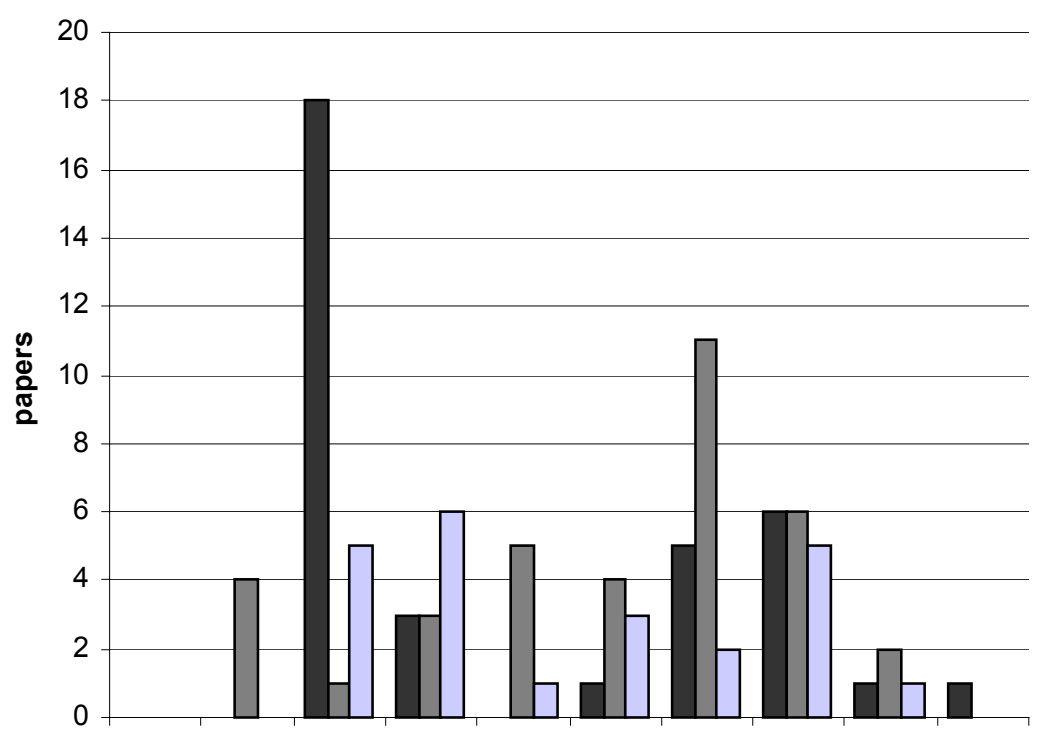

Social and Economical effects

$\square$ Consequences of the American policies $\square$ Internal BD

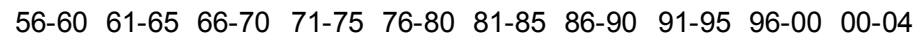


$B D$ in the rest of the world - Figure 3

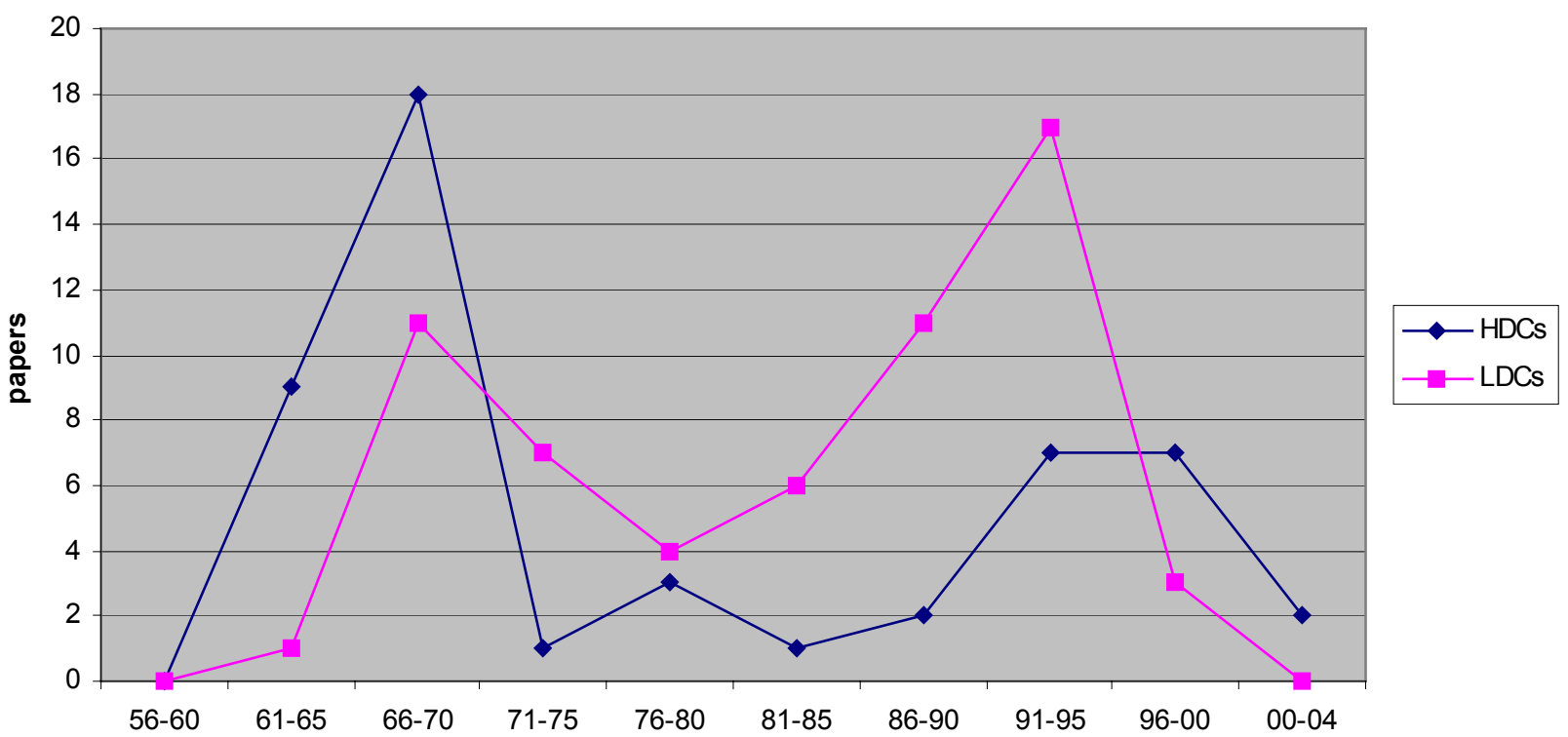

$B D$ in the rest of the world - Figure 4

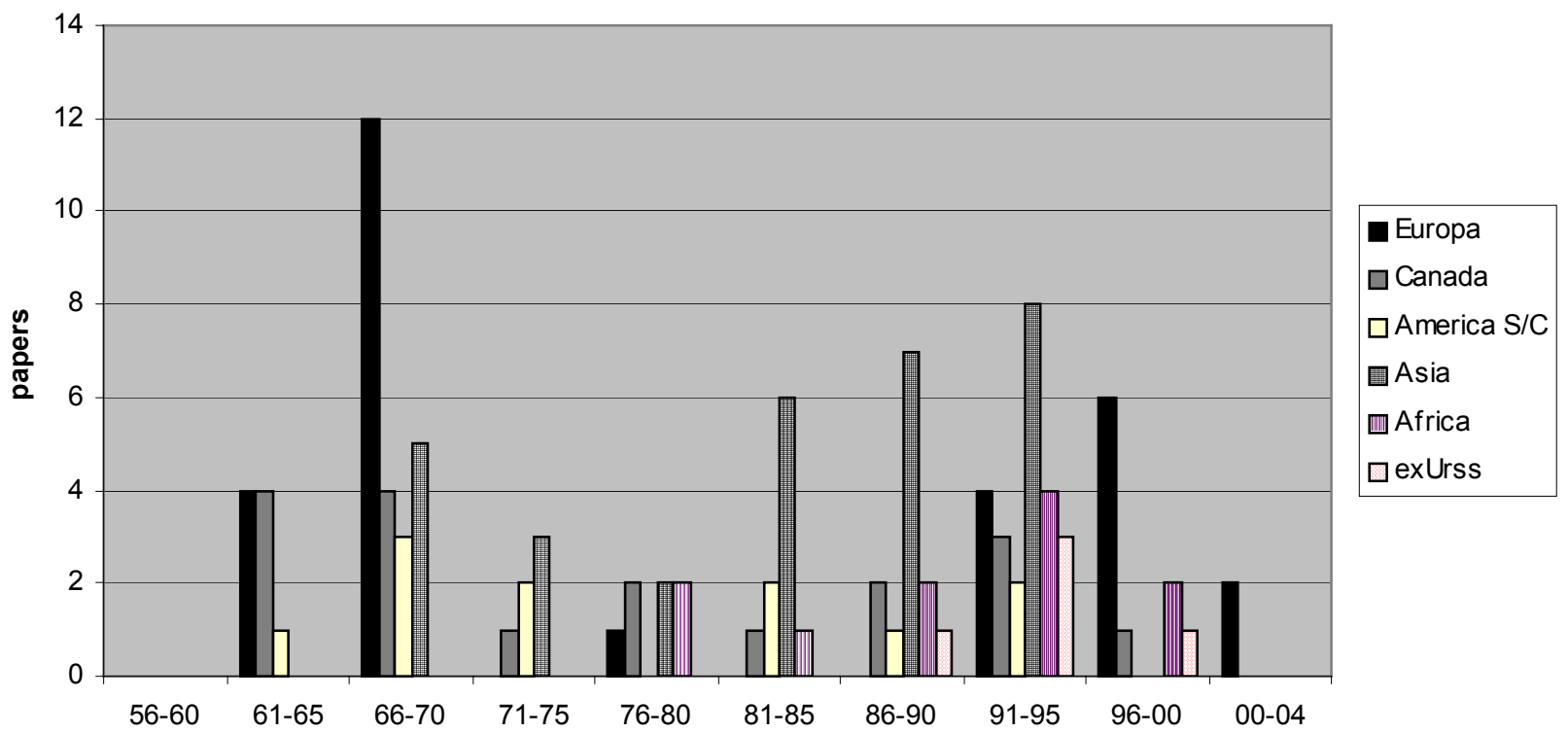


BD and International Coordination - Figure 5

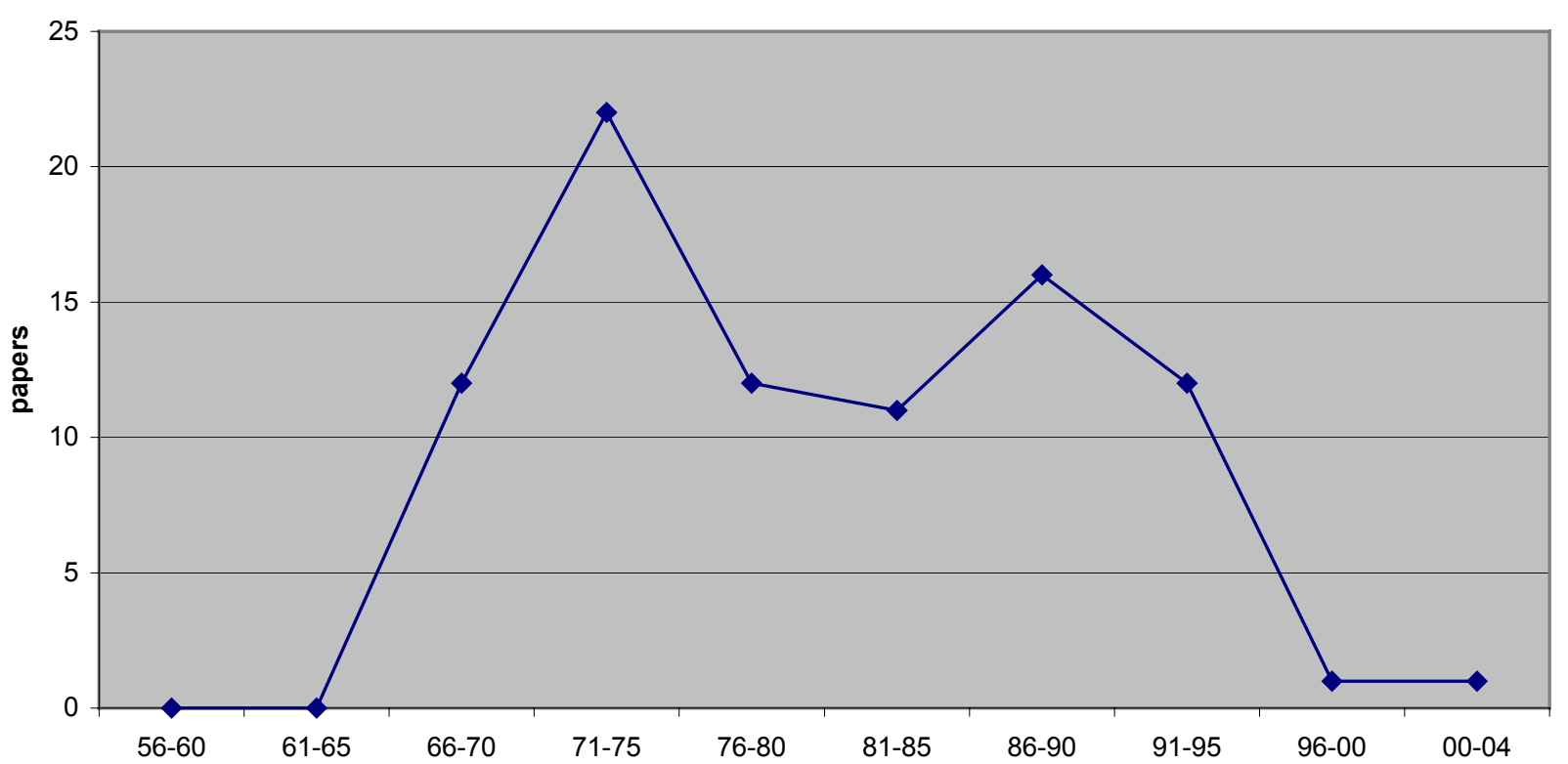

BD and International Coordination - Figure 6

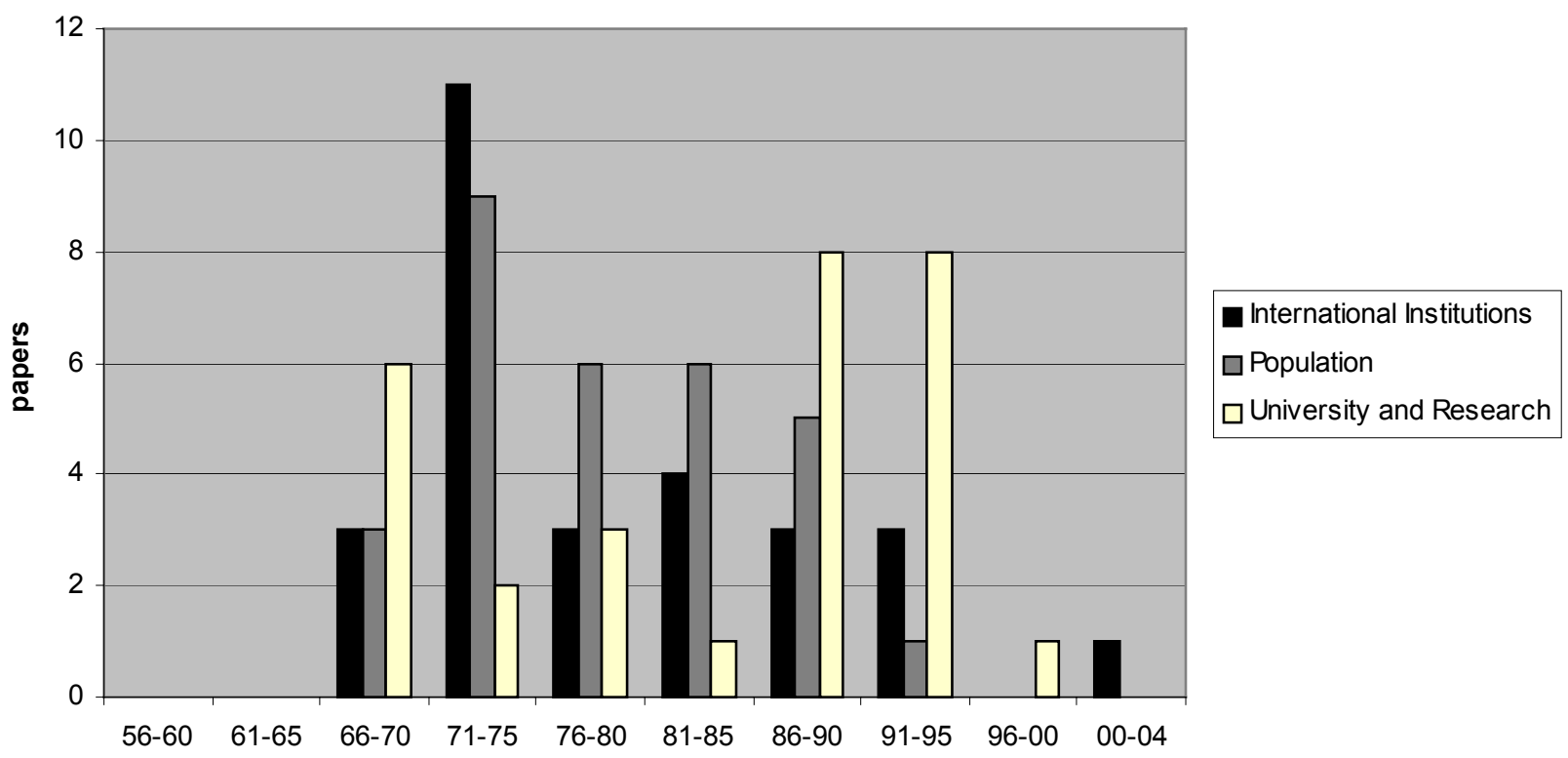


BD's Models - Figure 7

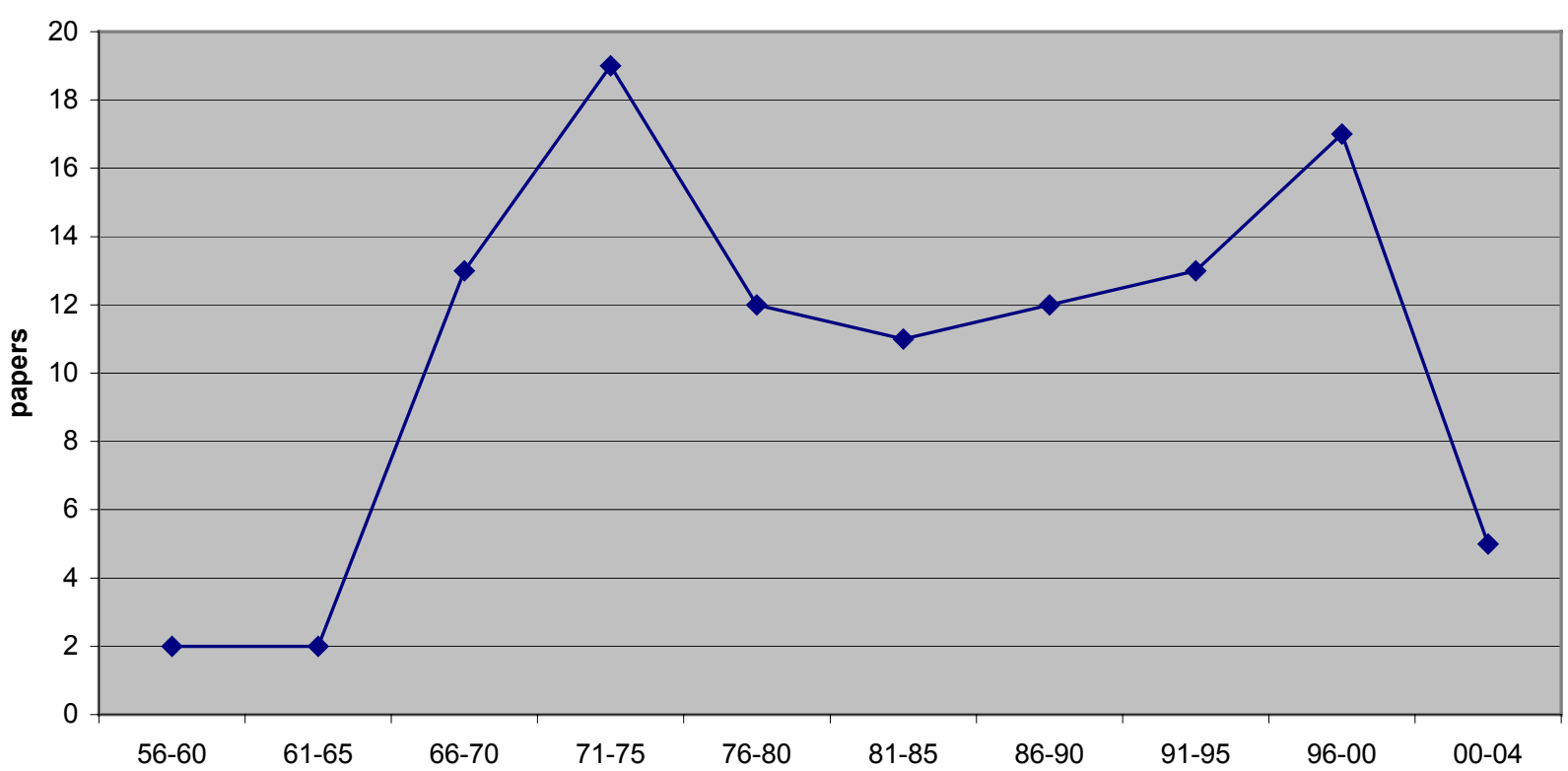

BD's Models - Figure 8

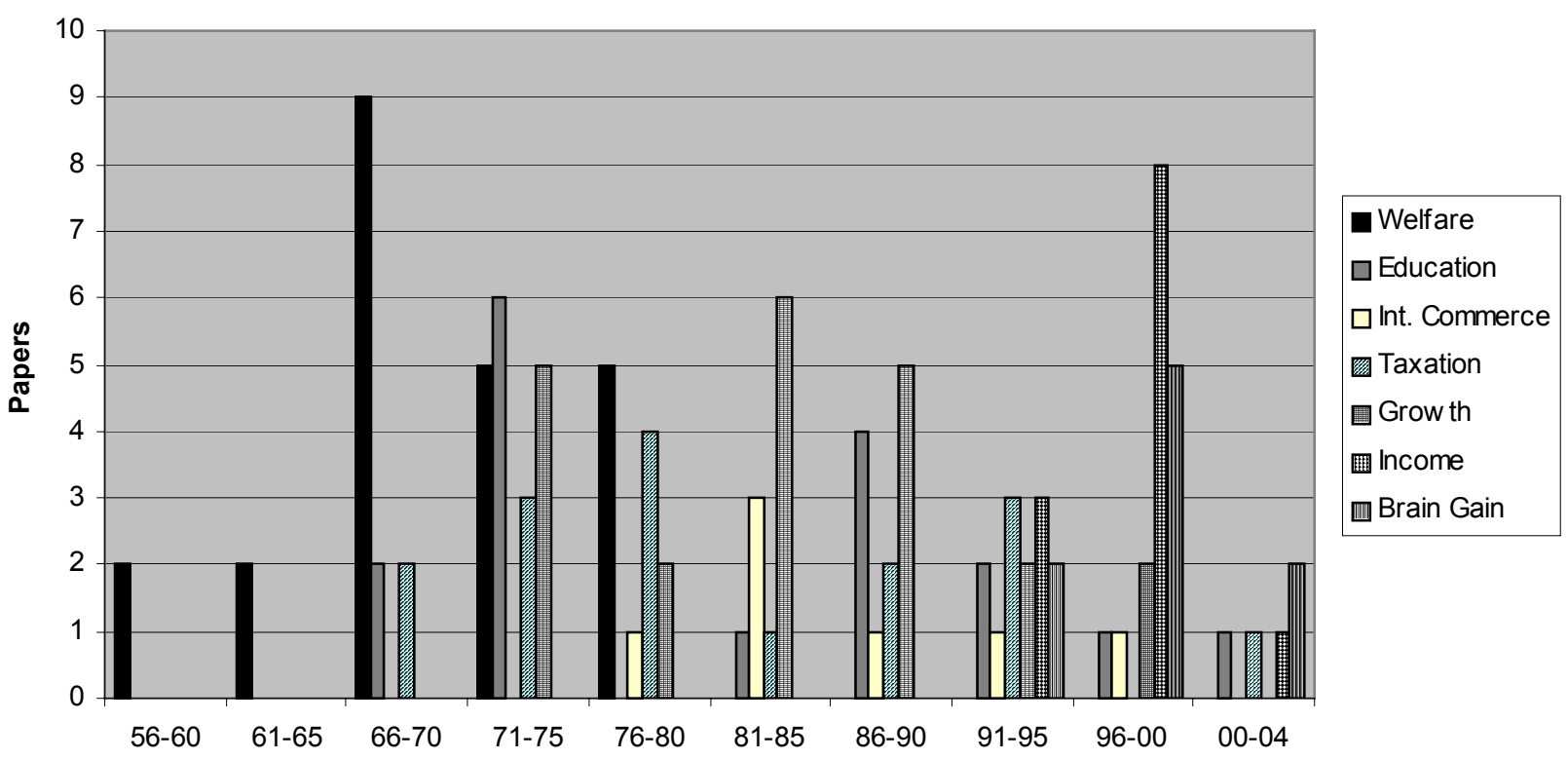




\section{REFERENCES}

1) Abrokwaa, C. K. (1999), Africa 2000: What Development Strategy? Journal of Black Studies, Vol. 29, No. 5, Special Issue: Political Strategies of Democracy and Health Issues and Concerns in Global Africa. pp. 646-668.

2) Abu-Rashed, J and Slottje, D.J. (1991) A Theoretical Analysis of. the Beneficial Effects of the Brain Drain Phenomenon Cambridge Journal of Economics, 15 (3).

3) Acemoglu, D. (1996), A Microfoundation for Social Increasing Returns in Human Capital Accumulation The Quarterly Journal of Economics, Vol. 111, No. 3. pp. 779-804.

4) Adams E. P. (1990), Benjamin Banneker Honors College: Gateway to Scientific and Technical Doctorates (in Programs and Application) Journal of Negro Education, Vol. 59, No. 3. pp. 449-462.

5) Adams, W. (ed.), 1968, The Brain Drain (NY Macmillan Company).

6) Ades, A. and R. Di Tella (1997), National Champions and Corruption: Some Unpleasant Interventionist Arithmetic The Economic Journal, Vol. 107, No. 443. pp. 1023-1042.

7) Agarwal, V. B. and D. R. Winkler (1985) United States immigration policy and indirect immigration of professionals. Economics of Education Review, Volume 4, 1, Pages 1-16.

8) Agarwal, V. B. and G. R. Yochum (1987) The Eilberg Act, new seed immigration, and professional labor markets. Economics of Education Review, Volume 6, 3, Pages 275-283

9) Akbar, S and Don J. Devoretz (1993) Canada's demand for Third World highly trained immigrants: $1976-86$. World Development, Volume 21, 1, Pages 177-187

10) Allen, H. L. (1991), The Mobility of Black Collegiate Faculty Revisited: Whatever Happened to the "Brain Drain"? Journal of Negro Education, Vol. 60, No. 1. pp. 97-109.

11) Arum, R (1996) Do Private Schools Force Public Schools to Compete? American Sociological Review,61,1,29-46.

12) Ayres R. L. (1975), Development Policy and the Possibility of a "Liveable" Future for Latin America The American Political Science Review, Vol. 69, No. 2. pp. 507-525.

13) Bachner S. (1973), Black Literature: The Junior Novel in the Classroom-Harlem Summer Negro American Literature Forum, Vol. 7, No. 1. pp. 26-27+31.

14) Bakken B. (1988), Backwards Reform in Chinese Education (in Studies) The Australian Journal of Chinese Affairs, No. 19/20. pp. 127-163.

15) Balacs, P. and A. Gordon (1975) Brain drain and income taxation: A UK case study. World Development, Volume 3, 10, Pages 677-703

16) Baldwin, (1970) Brain Drain or Overflow? Foreign Affairs, vol 48, 358-372

17) Bardhan, P. (1996), Efficiency, Equity and Poverty Alleviation: Policy Issues in Less Developed Countries (in Policy Forum: Poverty and Development) The Economic Journal, Vol. 106, No. 438. pp. 1344-1356.

18) Barnard G A (1986) Rescuing Our Manufacturing Industry-Some of the Statistical Problems Statistician,35,1, 3-16.

19) Bauer, T and F Zimmermann (1999) Assessment of possible migration pressure and its Labor market impact following EU enlargement to Central and Eastern Europe: Part 1. London HMSO.

20) Beauchamp E R(1975) Griffis in Japan: The Fukui Interlude, 1871 Monumenta Nipponica, 30, 4. 423-452.

21) Becker, G S; K M Murphy and R Tamura (1990) Human Capital, Fertility, and Economic Growth The Journal of Political Economy, 98,5, Part 2: The Problem of Development: A Conference of the Institute for the Study of Free Enterprise Systems. pp. S12-S37.

22) Beijer G (1966) Selective Migration for and 'Brain Drain' from Latin America' International Migration 1 (28).

23) Beijer G (1969) BD as a Burden, a Stimulus and a Challenge to European Integration in 'Population Growth and the Brain Drain' edited by F Bechhofer, University Press Edinburgh.

24) Beine, M. ; F. Docquier and H. Rapoport (2001) Brain drain and economic growth: theory and evidence. Journal of Development Economics, Volume 64, 1, Pages 275-289

25) Bell P. D. (1971), The Ford Foundation as a Transnational Actor (in Transnational Organizations) International Organization, Vol. 25, No. 3, Transnational Relations and World Politics. pp. 465-478.

26) Bellante, D. (1978) Changes in the migration of human capital and the southern "brain drain": Evidence from the censuses of 1960 and 1970. Journal of Behavioural Economics, Volume 7, 1, Pages 53-77

27) Benabou, R. (1993), Workings of a City: Location, Education, and Production The Quarterly Journal of Economics, Vol. 108, No. 3. pp. 619-652.

28) Benavot, A (1989), Education, Gender, and Economic Development: A Cross-National Study Sociology of Education, Vol. 62, No. 1, Special Issue on Gender and Education. pp. 14-32.

29) Beng C. S. (1990) Brain Drain in Singapore: Issues and Prospects Singapore Economic Review, 35 (2).

30) Berelson B (1975) The World Population Plan of Action: Where Now? Population and Development Review, 1, 1, pp. 115-146.

31) Berelson B (1976), Social Science Research on Population: A Review Population and Development Review, 2, 2 , pp. 219-266.

32) Berry, R. A. and R. Soligo, (1969), Some welfare effects of international migration Journal of political economy, 77, 778-794

33) Bhagwati, J. (1973) Education, class structure and income equality. World Development, Volume 1, 5. Pages 2136 
34) Bhagwati, J. (1979) International Migration of Highly skilled: economics, Ethics and Taxes, Third Word Quarterly $1(3), 17-30$.

35) Bhagwati, J. (1991), Economics Beyond the Horizon The Economic Journal, 101 (404). pp. 9-14.

36) Bhagwati, J. (ed.), 1976, The Brain Drain and taxation II Theory and empirical analysis. Amsterdam: North Holland.

37) Bhagwati, J. and J. D. Wilson ( ed). 1989. Income Taxation and International Mobility, Cambridge, MA: Mitt Pres.

38) Bhagwati, J. et al. (1975), The Brain Drain: a Symposium. J. Development Econ. 2 193-318

39) Bhagwati, J. N and K. Hamada, (1974), The Brain Drain, International Integration of Markets for professionals and Unemployment: A Theoretical Analysis Journal of Development Economics, 1

40) Bhagwati, J. N. ; K.-W. Schatz and K.-Y. Wong (1984) The West German gastarbeiter system of immigration. European Economic Review, Volume 26, 3, Pages 277-294

41) Bhagwati, J. N. and D. Rodriguez, (1975), Welfare-Theoretical Analyses of the Brain Drain, Journal of development Economics, 2 1961-221.

42) Bhagwati, J. N. and K. Hamada (1982) Tax policy in the presence of emigration. Journal of Public Economics, Volume 18, 3, Pages 291-317

43) Bhagwati, J. N. and M. Patrington ed. (1976) Taxing the Brain Drain: A proposal. Amsterdam: North Holland.

44) Bhagwati, J. N. and W. Dellafar, (1973), The Brain Drain and Income taxation World Development, $194-100$.

45) Bhagwati, J. N; H Wan, Jr. (1979), The "Stationarity" of Shadow Prices of Factors in Project Evaluation, with and without Distortions The American Economic Review, 69 (3). pp. 261-273.

46) Bird, B. J.; D. N. Allen (1989), Faculty Entrepreneurship in Research University Environments Journal of Higher Education, Vol. 60, No. 5. pp. 583-596.

47) Black, D ; V Henderson (1999), A Theory of Urban Growth The Journal of Political Economy, 107, 2. pp. $252-284$.

48) Blacks and Proposition 209: The Beginnings of a Black Brain Drain From the University of California (in News and Views) The Journal of Blacks in Higher Education, 15. pp. 50-52 (1997).

49) Blejer M. I. (1978), Income Per Capita and the Structure of Industrial Exports: An Empirical Study The Review of Economics and Statistics, Vol. 60, No. 4. pp. 555-561.

50) Blomqvist A. G. (1986), International Migration of Educated Manpower and Social Rates of Return to Education in LDCS International Economic Review, Vol. 27, No. 1. pp. 165-174.

51) Boadway R. and F. Flatters (1982), Efficiency and Equalization Payments in a Federal System of Government: A Synthesis and Extension of Recent Results The Canadian Journal of Economics, Vol. 15, No. 4. pp. 613-633.

52) Bodenhofer H-J (1967) The mobility of labour and the Theory of human capital The Journal of human resource, 2 , 431-448.

53) Borjas, G J (1987) Self-Selection and the Earnings of Immigrants The American Economic Review, 77, 4, $531-553$.

54) Boyd M. (1976), Immigration Policies and Trends: A Comparison of Canada and the United States Demography, Vol. 13, No. 1. pp. 83-104.

55) Brandt W. and R. S. McNamara (1980), The Brandt Commission's Findings on Population (in Documents) Population and Development Review, Vol. 6, No. 2. pp. 335-343.

56) Brass W. (1974), Perspectives in Population Prediction: Illustrated by the Statistics of England and Wales Journal of the Royal Statistical Society. Series A (General), 137 (4) pp. 532-583.

57) Brass W. (ed), 1969 Population Growth and the Brain Drain edited by F. Bechhofer, Edinburgh: Ed University Pres

58) Bryce-Laporte R. S. (1972), Black Immigrants: The Experience of Invisibility and Inequality Journal of Black Studies, Vol. 3, No. 1, Inequality and the Black Experience: Some International Dimensions. pp. 29-56.

59) Bucovetsky, S. (2003) Efficient migration and redistribution Journal of Public Economics, Volume 87, 11, Pages 2459-2474.

60) Buiter, W. H. And K. M. Kletzer (1992) Fiscal policy coordination as fiscal federalism : Economic integration, public goods and efficiency in growing economies. European Economic Review, Volume 36, 2-3, Pages 647-653

61) Bushnell, P.; Choy. W.K. (2001). Go west, young man, go west? Treasury Working Paper 1/7 Wellington.

62) Caldwell, J.; P. Caldwell and B. Caldwell (1987), Anthropology and Demography: The Mutual Reinforcement of Speculation and Research Current Anthropology, Vol. 28, No. 1. pp. 25-43.

63) Carrington, W. J.; E. Detragiache; Tara Vishwanath (1996), Migration with Endogenous Moving Costs The American Economic Review, Vol. 86, No. 4. pp. 909-930.

64) Cassen R. and T. Dyson (1976), New Population Projections for India (in Data and Perspectives) Population and Development Review, Vol. 2, No. 1. pp. 101-136.

65) Caves, R. E. (1984), Harry Johnson as a Social Scientist The Journal of Political Economy, 92, 4, 642-658.

66) Center for Policy Studies of the Population Council Population and Development Review, 6, 1. pp. 126-152.

67) Chang, R (1995) Private Investment and Sovereign Debt Negotiations International Economic Review, 36, 2. pp. 387-405.

68) Chau, N H (2001) Strategic Amnesty and Credible Immigration Reform Journal of Labor Economics, 19,3, $604-634$.

69) Chen T-J, and H-Y Su (1995) On the Job Training as a Cause of Brain Drain. Weltwirtsch Arch., 131 (3), $526-41$.

70) Cheng, J. Y. S. (1990), Prospects for Democracy in Hong Kong After the Beijing Massacre The Australian Journal of Chinese Affairs, No. 23. pp. 161-185. 
71) Chiswick, B R (1986a), Is the New Immigration Less Skilled Than the Old? Journal of Labor Economics, 4, 2. pp. 168-192.

72) Chiswick, B R (1986b), Comment: [Immigration as a Counter to Below-Replacement Fertility in the United States] (in Consequences) Population and Development Review, Vol 12, Supplement: Below-Replacement Fertility in Industrial Societies: Causes, Consequences, Policies. pp. 269-270.

73) Chiswick, C. U. (1989), The Impact of Immigration on the Human Capital of Natives Journal of Labor Economics, Vol. 7, No. 4. pp. 464-486.

74) Coleman D A (1993) Contrasting Age Structures of Western Europe and of Eastern Europe and the Former Soviet Union: Demographic Curiosity or Labor Resource? Population and Development Review, 19, 3, pp. $523-555$.

75) Corden W. M. (1984), Harry Johnson's Contributions to International Trade Theory The Journal of Political Economy, Vol. 92, No. 4. pp. 567-591.

76) Cox R W (1971), Labor and Transnational Relations (in Issue Areas) International Organization, Vol. 25, No. 3, Transnational Relations and World Politics. pp. 554-584.

77) Cox R W (1979), Ideologies and the New International Economic Order: Reflections on Some Recent Literature (in Review Essay) International Organization, Vol. 33, No. 2. pp. 257-302.

78) Crafts N F R.; N J Ireland (1976), A Simulation of the Impact of Changes in Age at Marriage Before and During the Advent of Industrialization in England Population Studies, Vol. 30, No. 3. pp. 495-510.

79) Crouzet F (1971), The Economic History of Modern Europe (in Economic History: Retrospect and Prospect) The Journal of Economic History, 31 (1), The Tasks of Economic History. pp. 135-152.

80) Dalen van, H. P. (1993) International migration, economic policy and human capital accumulation : A simulation study. Economic Modelling, Volume 10, 4 Pages 417-430

81) Dauderstädt, M (2001) Ways, Byways and third ways to a social and democratic Europe. Eurokolleg 44.

82) Davenport, S. (2004) Panic and panacea: brain drain and science and technology human capital policy. Research Policy, Volume 33, 4, Pages 617-630

83) Davies J B; I Wooton (1992), Income Inequality and International Migration. The Economic Journal, 102, 413, pp. 789-802.

84) De Seynes, P. (1972) Prospects for a Future Whole World International Organization, 26, 1, pp. 1-17.

85) Devoretz, D. and D. Maki (1975) The brain drain and income taxation: Canadian estimates. World Development, Volume 3, 10, Pages 705-716

86) Devoretz, D. and D. Maki (1983). The immigration of Third World professionals to Canada: 1968-1973 . World Development, Volume 11, 1, Pages 55-64

87) Diaz-Alejandro C. F. (1975), North-South Relations: The Economic Component International Organization, Vol. 29, No. 1, World Politics and International Economics. pp. 213-241.

88) Dittmer L (1981) The Strategic Triangle: An Elementary Game-Theoretical Analysis World Politics, 33,4, 485-515.

89) Djajic, S. and R. Milbourne (1988) A general equilibrium model of guest-worker migration : The source-country perspective. Journal of International Economics, Volume 25, 3-4, Pages 335-351

90) Djajic, S. (1985), Human Capital, Minimum Wage and Unemployment: A Harris-Todaro Model of a Developed Open Economy Economica, New Series, Vol. 52, No. 208. pp. 491-508.

91) Djajic, S. (1989), Skills and the Pattern of Migration: The Role of Qualitative and Quantitative Restrictions on International Labor Mobility International Economic Review, Vol. 30, No. 4. pp. 795-809.

92) Docquier, F.; Rapoport, H. (1997) La fuite de Cerveux, una chancepour les pays en developpement? Meeting of the French Economic Association. Paris, September.

93) Dookhan I. (1981), The Expansion of Higher Educational Opportunities in the United States Virgin Islands Journal of Negro Education, Vol. 50, No. 1. pp. 15-25.

94) Dore R. P. (Winter, 1972-1973), The Importance of Educational Traditions: Japan and Elsewhere Pacific Affairs, Vol. 45, No. 4. pp. 491-507.

95) Edding F. and H. J. Bodenhofer, (1966) Communication on movements of intellectuals Council of Europe, European Population Conference, Strasburg, 1966, CDE . C 33.

96) Ehie, I. C.; D. K. Smith Jr. (1994), OR Utilization in Nigeria: A Sample Survey (in Review Paper) The Journal of the Operational Research Society, Vol. 45, No. 1. pp. 31-37.

97) Ehrenberg, R G (1992) The Flow of New Doctorates Journal of Economic Literature, 30, 2, pp. 830-875.

98) Elmore, C. J. and R T. Blackburn (1983), Black and White Faculty in White Research Universities Journal of Higher Education, Vol. 54, No. 1. pp. 1-15.

99) Emigration of Scientist from the United Kingdom, Report of Royal Society (London 1963).

100) Engerman, S. L.; R. W. Jones (1997), International Labor Flows and National Wages (in Economic Development and International Trade) The American Economic Review, Vol. 87, No. 2, Papers and Proceedings of the Hundred and Fourth Annual Meeting of the American Economic Association. pp. 200-204.

101) Epstein L. (1974), Some Economic Effects of Immigration: A General Equilibrium Analysis The Canadian Journal of Economics, 7, 2, pp. 174-190.

102) Espenshade, T. J.and J. J. Minarik (1987), Demographic Implications of the 1986 US Tax Reform (in Notes and Commentary) Population and Development Review, Vol. 13, No. 1. pp. 115-127.

103) Ethier W J (1985) International Trade and Labor Migration The American Economic Review, 75, 4, 691-707. 
104) Ethier W J (1986) Illegal Immigration: The Host-Country Problem The American Economic Review, 76, 1, 56-71.

105) Fahim H. and K. Helmer (1980), Indigenous Anthropology in Non-Western Countries: A Further Elaboration Current Anthropology, Vol. 21, No. 5. pp. 644-663.

106) Farid S. M. (1974), On the Tempo of Childbearing in England and Wales Population Studies, 28,1 , pp. $69-83$.

107) Field, J. A. (1971), Transnationalism and the New Tribe (in Transnational Relations: The Nature of the Beast) International Organization, Vol. 25, No. 3, Transnational Relations and World Politics. pp. 353-372.

108) Fisher, I. (1897) Senses of Capital. Economic Journal. VII, 199-213.

109) Fisher, I. (1927) ed. The Nature of Capital Income. London: Macmillan \& Co.

110) Fogel, W. (1980), United States Immigration Policy and Unsanctioned Migrants (in Immigration Issues in an Era of Unsanctioned Migration: A Symposium) Industrial and Labor Relations Review, 33, 3, pp. 295-311.

111) Friedman, S. (1973) The effect of the US Immigration Act of 1965 on the flow of skilled migrants from less developed countries. World Development, Volume 1, 8, Pages 39-44

112) Funkhouser, E (1992) Migration from Nicaragua: some recent evidence World Development, Volume 20, 8, Pages 1209-1218

113) Geiger, R L. (1990), Organized Research Units--Their Role in the Development of University Research, Journal of Higher Education, Vol. 61, No. 1. pp. 1-19.

114) Gish, Oscar and Martin Goofrey (1979) A reappraisal of the Brain Drain. With special reference to the medical profession. Social Science and Medicine 13C: 1-11.

115) Glaser, W. A, (eds 1978) The Brain Drain: Emigration and Return

116) Glaz'ev, S I and L P Malkov (1992) The “Brain Drain” and Social Consciousness Prob. Econ. Transition, 35 (6), pp. 50-54.

117) Gmelch, G. (1980), Return Migration Annual Review of Anthropology, Vol. 9. pp. 135-159.

118) Goldfarb, R.; O. Havrylyshy and S. Mangum (1984) Can remittances compensate for manpower outflows : The case of Philippine physicians Journal of Development Economics, Volume 15, 1-3, Pages 1-17

119) Goodfriend, Marvin; John McDermott (1998), Industrial Development and the Convergence Question The American Economic Review, Vol. 88, No. 5. pp. 1277-1289.

120) Gould, D M (1994), Immigrant Links to the Home Country: Empirical Implications for U.S. Bilateral Trade Flows The Review of Economics and Statistics, Vol. 76, No. 2. pp. 302-316.

121) Greenwood M J (1975), Research on Internal Migration in the United States: A Survey Journal of Economic Literature, Vol. 13, No. 2. pp. 397-433.

122) Greenwood M J (1983), Leading Issues of Fact and Theory (in Economics of Mass Migration from Poor to Rich Countries) The American Economic Review, 73 (2), Papers and Proceedings of the 95th Annual Meeting of the American Economic Association. pp. 173-177.

123) Greenwood M J. and J M McDowell (1991) Differential Economic Opportunity, Transferability of Skills, and Immigration to the United States and Canada The Review of Economics and Statistics, 73, 4. pp. 612-623.

124) Greenwood M J; J M McDowell (1986), The Factor Market Consequences of U.S. Immigration Journal of Economic Literature, Vol. 24, No. 4. pp. 1738-1772.

125) Griffin, K. (1976) On the emigration of the peasantry. World Development, Volume 4, 5, Pages 353-361

126) Grubel, H G and A Scott (1976), The immigration of scientists and engineers to the United States, 1949-61, The Journal of political economy, 74, 368-378.

127) Grubel, H G and A Scott (1977), ed. The Brain Drain Waterloo; sir Wilfrid Laurier University Press.

128) Grubel, H G and A D Scott, (1966a), The international flow of Human Capital" American Economic Review, $56,268-274$.

129) Grubel, H G and A D Scott (1966b), The International Flow of Human Capital, the Brain Drain" American Economic Review, 268-274.

130) Haas, E B (1975), Is there a Hole in the Whole? Knowledge, Technology, Interdependence, and the Construction of International Regimes International Organization, Vol. 29, No. 3, International Responses to Technology. pp. 827-876.

131) Hall M-F (1973), Population Growth: U.S. and Latin American Views: An Interpretation of the Response of the United States and Latin America to the Latin American Population Growth Population Studies, 27 (3) $415-429$.

132) Hamada, K. (1975) Efficiency, equality, income taxation and the brain drain : A second-best argument. Journal of Development Economics, Volume 2, 3, Pages 281-287

133) Hamada, K. and J. Bhagwati (1975) Domestic distortions, imperfect information and the brain drain. Journal of Development Economics, Volume 2, 3, Pages 265-279

134) Hamada, K. ed (1977) Taxing the Brain Drain: a global point of view The new international order, edited by J. Bhagwati. Cambridge, Mass.: MIT Press

135) Hannum, Hurst (1987), The Strasbourg Declaration on the Right to Leave and Return (in Current Developments) American Journal of International Law, Vol. 81, No. 2. pp. 432-438.

136) Hantke, J. (1983), The 1982 Session of the UN Sub-Commission on Prevention of Discrimination and Protection of Minorities (in Current Developments) American Journal of International Law, 77, 3, pp. 651-662. 
137) Harberger, A. C. and D. Wall (1984) Harry G. Johnson as a Development Economist The Journal of Political Economy, Vol. 92, No. 4. pp. 616-641.

138) Hartnett, R. T. (1987), Has There Been a Graduate Student "Brain Drain" in the Arts and Sciences? Journal of Higher Education, Vol. 58, No. 5. pp. 562-585.

139) Hayhoe, R. (1988), Shanghai as a Mediator of the Educational Open Door Pacific Affairs, 61, 2, $253-284$.

140) Heckman, J.; A. Layne-Farrar and P. Todd (1996), Human Capital Pricing Equations with an Application to Estimating the Effect of Schooling Quality on Earnings (in Symposium on School Quality and Educational Outcomes) The Review of Economics and Statistics, Vol. 78, No. 4. pp. 562-610.

141) Heilbron J L; D J Kevles (1988), Science and Technology in U.S. History Textbooks: What's There-and what Ought to be There Reviews in American History, Vol. 16, No. 2. pp. 173-185.

142) Hellerstein, J. K. (1998), Public Funds, Private Funds, and Medical Innovation: How Managed Care Affects Public Funds for Clinical Research (in What We Get for Health-Care Spending) The American Economic Review, Vol. 88, No. 2, Papers and Proceedings of the Hundred and Tenth Annual Meeting of the American Economic Association. pp. 112-116.

143) Helliwell J F (1999) Checking the brain drain: evidence and implications. IRPP Option Politiques.

144) Hill, J. K. and J. E. Pearce (1990), The Incidence of Sanctions Against Employers of Illegal Aliens The Journal of Political Economy, Vol. 98, No. 1. pp. 28-44.

145) Hirschman A. O. (1978), Exit, Voice, and the State World Politics, Vol. 31, n 1. pp. 90-107.

146) Hirschman A. O.; R. R. Nelson (1976), Discussion (in Political Economy: Some Uses of the Exit-Voice Approach) The American Economic Review, Vol. 66, No. 2, Papers and Proceedings of the Eighty-eighth Annual Meeting of the American Economic Association. pp. 386-391.

147) Ho S. P. (1975), Industrialization in Taiwan: Recent Trends and Problems Pacific Affairs, 48, 1. pp. $27-41$.

148) Hobcraft, J.; J. Menken and S. Preston (1982), Age, Period, and Cohort Effects in Demography: A Review (in Current Items) Population Index, Vol. 48, No. 1. pp. 4-43.

149) Hochschild, A. R. (1973), A Review of Sex Role Research American Journal of Sociology, Vol. 78, No. 4, Changing Women in a Changing Society. pp. 1011-1029.

150) Hoffman A. (Winter, 1995-1996), The Destruction of Higher Education in Sub-Saharan Africa The Journal of Blacks in Higher Education, No. 10. pp. 83-87.

151) Hogan W. W. (1991), Economic Reforms in the Sovereign States of the Former Soviet Union (in Symposium on the Soviet Economy after Communism) Brookings Papers on Economic Activity, 1991, 2. 303-319.

152) Holmes J. W. (1974), Impact of Domestic Political Factors on Canadian-American Relations: Canada (in National Attitudes) International Organization, Vol. 28, No. 4, Canada and the United States: Transnational and Transgovernmental Relations. pp. 611-635.

153) Hooks. G. (1990), The Rise of the Pentagon and U.S. State Building: The Defense Program as Industrial Policy American Journal of Sociology, Vol. 96, No. 2. pp. 358-404.

154) Huang, W.-C. (1988), An empirical analysis of foreign student brain drain to the United States. Economics of Education Review, Volume 7, 2, Pages 231-243

155) Hull, C. R. ed. (1899) The Economic writing of sir William Petty. 2 vol. Cambridge: Cambridge Univ. press.

156) Huntington, S. P. (1988), One Soul at a Time: Political Science and Political Reform (in Articles) The American Political Science Review, Vol. 82, No. 1. pp. 3-10.

157) Ishikawa, J. (1996), Scale Economies in Factor Supplies, International Trade, and Migration The Canadian Journal of Economics, Vol. 29, No. 3. pp. 573-594.

158) Johnson H G (1965a) The economics of Brain Drain in Sixth seminar on Canadian-American relations, edited by F.J. Boland. Windsor Ontario: The Canadian Case". Minerva 3 (1965): 299-311. also as The technology Gap and the Brain Drain: III in Defence, Science and Public Policy, edited by Edwin S. Mansfield. NY Norton, 1968 .

159) Johnson H G (1965b) The economics of Brain Drain: Correspondence. Minerva 4: 273-274

160) Johnson H G (1965c) The economics of the Brain Drain: the Canadian case, Minerva, Review of science, learning and policy, vol III.

161) Johnson H G (1969a) Some Economics Aspects of Brain Drain with appendix Note on the effects of migration of professional people on the Welfare of those remaining behind Pakistan Development review 7: 379-411. also in International Monetary System, J. Econ. Studies 2: 3-33. also in Pakistan Development, 7:1-28. also in Italian in Rivista di Politica Economica, 58 [1968] also in International Finance: Selected readings, Edited by R N Cooper Harmondsworth. Penguin.

162) Johnson H G (1969b) The International Circulation of Human Capital: Comment. Minerva 6: 105-112. also as Criticisms of Thomas's Analysis of Brain Drain in Economics of Education: Selected readings. Vol 2 Edited by Mark Blaug. Harmondsworth: Penguin.

163) Johnson H G (1972) Labour mobility and the Brain Drain Paper presented at the International Economic Association Conference, Bled, Yougoslavia, in The gap between rich and poor Nations edited by Gustav Ranis, London. Macmillan.

164) Johnson H G (1975) Me and my Brain Drain Punch, 30. Inflation Energy and the world economy: prospects for international Cooperation Pannel statement presented at the quadrangular conference II, Washington.

165) Jonas J (1965) Why doctors emigrate, Social Commentary, 5. 
166) Jordan R S (1976) UNITAR and UN Research (in Comments and Current Views) International Organization, 30, 1, pp. 163-171.

167) Jurgens, U ; L Klinzing; L Turner (1993), The Transformation of Industrial Relations in Eastern Germany Industrial and Labor Relations Review, Vol. 46, No. 2. pp. 229-244.

168) Katz E; O Stark (1984) Migration and Asymmetric Information: Comment The American Economic Review, 74, 3, pp. 533-534.

169) Katz, E ; O Stark (1987) International Migration Under Asymmetric Information The Economic Journal, 97, 387, pp. 718-726.

170) Kay J. A. (1990), Tax Policy: A Survey The Economic Journal, Vol. 100, N. 399. pp. 18-75.

171) Kearney, Michael (1986), From the Invisible Hand to Visible Feet: Anthropological Studies of Migration and Development Annual Review of Anthropology, Vol. 15. pp. 331-361.

172) Keely, C. B. (1971), Effects of the Immigration Act of 1965 on Selected Population Characteristics of Immigrants to the United States Demography, Vol. 8, No. 2. pp. 157-169.

173) Keely, C. B. (1975), Effects of U. S. Immigration Law on Manpower Characteristics of Immigrants Demography, Vol. 12, No. 2. pp. 179-191.

174) Keohane, R. O.; J. S. Nye (1974), Transgovernmental Relations and International Organizations World Politics, Vol. 27, No. 1. pp. 39-62.

175) Kesselman, J (1988) Policies to stem the BD without Americanising Canada. Canada Public Policy.

176) Khanna, T. ; M. Iansiti (1997), Firm Asymmetries and Sequential R\&D: Theory and Evidence from the Mainframe Computer Industry Management Science, Vol. 43, No. 4, Frontier Research in Manufacturing and Logistics. pp. 405-421.

177) Kindleberger, C. P.(1986), International Public Goods without International Government The American Economic Review, Vol. 76, No. 1.pp. 1-13.

178) King T (1983) Immigration from Developing Countries: Some Philosophical Issues Ethics, 93, 3. pp. $525-536$.

179) Kitagawa, E M (1977) On Mortality (in Presidential Address) Demography, 14 (4) 381-389.

180) Kossoudji, S. A. (1989), Immigrant Worker Assimilation: Is It a Labor Market Phenomenon? The Journal of Human Resources, Vol. 24, No. 3. pp. 494-527.

181) Krieg, R M; C Wheelan (1995), A Nation Divided by Its Schools The Journal of Blacks in Higher Education, 7 , pp. 81-85.

182) Krugman, P. and J N Bhagwati (1976).The Decision to migrate: a Survey In The Brain Drain and Taxation, vol

2. Theory and Empirical Analysis. Edited by J N Bhagwati. Amsterdam. North Holland.

183) Kuper, A. (1983), Change of Life at the ASA (in Social Anthropology in the 1980's: A Symposium), RAIN, No. 56. pp. 10-11.

184) Kwok P; H Leland (1982), An Economic Model of the Brain Drain The American Economic Review, 72, 1. pp. 91-100.

185) Kwok P; H Leland (1984), Migration and Asymmetric Information: Reply The American Economic Review, 74, 3. p. 535.

186) Laitin D. (1994) The tower of Babel as a coordination Game: Political linguistic in Ghana. The American Political Science Review, 88, 3, p 622-634.

187) Last J M (1963) Migration of British Doctors of Australia Brit. Med. Journal, 2

188) Last J M (1969) International Mobility in the Medical Profession in 'Population Growth and the Brain Drain' edited by F Bechhofer, University Press Edinburgh.

189) Levin, S G; P E Stephan (1991), Research Productivity Over the Life Cycle: Evidence for Academic Scientists The American Economic Review, Vol. 81, No. 1. pp. 114-132.

190) Lewis J P (1991), Some Consequences of Giantism: The Case of India World Politics, 43, 3, pp. $367-389$.

191) Library of Congress (1974) Brain Drain: A study of the persistent issue of international scientific mobility prepared for the sub Committee on National Security Policy and Scientific Developments of the Committee on Foreign Affairs, US house of representatives, Wash. DC

192) Lidgard, J.; Gilson , C. (2001) Return migration of New Zealanders: a profile. In Proceedings of PANZ Conference, June p 1-20.

193) Lien, D. D. (1988) Appropriate scientific research and brain drain : A simple model. Journal of Development Economics, Volume 29, 1, Pages 77-87.

194) Lien, D. D. (1988) Asymmetric information and multi-stage brain drain Economics Letters, Volume 23, 3, Pages 305-309

195) Lien, D. D. (1988) Economic analysis of brain drain. Journal of Development Economics, Volume 25, 1, Pages 33-43

196) Lipset, S M (1993), Culture and Economic Behavior: A Commentary Journal of Labor Economics, 11 (1), Part 2: U.S. and Canadian Income Maintenance Programs. pp. S330-S347.

197) List, F. (1928) ed. The Nation system of political economy. Translated by Sampson S. Lloyd. New York: Longmans, Green \& Co.

198) Longawa V M (1984) Harry G. Johnson: A Bibliography The Journal of Political Economy, 92, 4, 659-711.

199) Lucas, R. (1987), Emigration to South Africa's Mines The American Economic Review, 77, 3, 313-330. 
200) Lucas, R. (1988), On mechanics of economic development Journal of Monetary Economics, 22, 3-42.

201) Lucas, R. (1975) The supply-of-immigrants function and taxation of immigrant's incomes : An econometric analysis. Journal of Development Economics, Volume 2, 3, Pages 289-308

202) Lund, Erik (1998), The Industrial History of Strategy: Reevaluating the Wartime Record of the British Aviation Industry in Comparative Perspective, 1919-1945 The Journal of Military History, Vol. 62, No. 1. pp. 75-99.

203) Lundahl, M. (1985) Brain drain, illegal migration and capital exports from less developed economies : A neoclassical approach. Economics Letters, Volume 17, 3, Pages 277-280

204) Lundberg, Shelly; Richard Startz, (1998), On the Persistence of Racial Inequality Journal of Labor Economics, Vol. 16, No. 2. pp. 292-323.

205) Lyons J E ( 1974), A Survey of Black Connecticut High School Graduates Attending Out-of-State Colleges and Universities Journal of Negro Education, Vol. 43, No. 4. pp. 506-511.

206) Ma, Shu-Yun (1993), The Exit, Voice, and Struggle to Return of Chinese Political Exiles Pacific Affairs, Vol. 66, No. 3. pp. 368-385.

207) MacNeill, I (1993), A Conversation with David J. Finney Statistical Science, 8, (2) 187-201.

208) Madhavan M. C. (1985), Indian Emigrants: Numbers, Characteristics, and Economic Impact Population and Development Review, Vol. 11, No. 3. pp. 457-481.

209) Malecki , E. J. (1981) Science, technology, and regional economic development: Review and prospects. Research Policy, Volume 10, 4, Pages 312-334

210) Malek, M. (1991) The impact of Iran's islamic revolution on health personnel policy. World Development, Volume 19, 8, Pages 1045-1054

211) Markusen, J. R. (1988), Production, Trade, and Migration with Differentiated, Skilled Workers The Canadian Journal of Economics, Vol. 21, No. 3. pp. 492-506.

212) Marshall, A. (1959) ed. Principles of Economics. New York: Macmillan Co.

213) Matthews, B. (1995), University Education in Sri Lanka in Context: Consequences of Deteriorating Standards Pacific Affairs, Vol. 68, No. 1. pp. 77-94.

214) McCain J A (1979) Higher Education in Ghana: Implications for the Future Journal of Black Studies, 10, 1, pp. 60-68.

215) McCain J A (1980) National Development and Higher Education in Ghana Journal of Negro Education, $49,1$. pp. 91-96.

216) McCulloch R and J Yellen, (1975) Consequences of a tax on the Brain Drain for unemployment and Income Inequality in LDCs Journal of Development Economics, 2 249-264.

217) McCulloch R; J Yellen (1977) Factor Mobility, Regional Development, and the Distribution of Income The Journal of Political Economy, Vol. 85, No. 1. pp. 79-96.

218) McDougall, W. A. (1982), Technocracy and Statecraft in the Space Age--Toward the History of a Saltation The American Historical Review, Vol. 87, No. 4. pp. 1010-1040.

219) McNicoll, G. (1984), Consequences of Rapid Population Growth: An Overview and Assessment Population and Development Review, Vol. 10, No. 2. pp. 177-240.

220) Mejia et al. Ed (1979) Physician and Nurse Migration : Analysis and policy implication. Geneva: World Health Organization. $476 \mathrm{pp}$

221) Meron T (1976) Staff of the United Nations Secretariat: Problems and Directions American Journal of International Law, 70, 4, pp. 659-693.

222) Meyer J W (1977) The Effects of Education as an Institution American Journal of Sociology, 83, 1, pp. $55-77$.

223) Mick, S S (1987), Sector Theory, Stratification, and Health Policy: Foreign and U.S. Medical Graduates in Medical Practice Journal of Health and Social Behavior, 28 (1) 74-88.

224) Mill, J. S. (1909) ed. Principles of Political Economy. New York: Longmans, Green \& Co.

225) Miller, C. L. (1981), Higher Education for Black Americans: Problems and Issues Journal of Negro Education, Vol. 50, No. 3, The Higher Education of Blacks in a Changing, Pluralistic Society. pp. 208-223.

226) Mills, W deB. (1986) Gorbachev and the Future of Sino-Soviet Relations Political Science Quarterly, 101, 4, pp. 535-557.

227) Miro C A and J. E. Potter (1980), Social Science and Development Policy: The Potential Impact of Population Research Population and Development Review, 6, 3, pp. 421-440.

228) Miyagiwa, K (1989), Human Capital and Economic Growth in a Minimum-Wage Economy International Economic Review, Vol. 30, No. 1. pp. 187-202.

229) Miyagiwa, K (1991), Scale Economies in Education and the Brain Drain Problem International Economic Review, 32, 3, pp. 743-759.

230) Mohan, L. and A. S. Bean (1976), Operational Research in India: An Evaluation of the Current State of the Art vis-a-vis Potential (in General Papers) Operational Research Quarterly (1970-1977), 27, 3, Part 1, $547-565$.

231) Mommsen K G (1973) Professionalism and the Racial Context of Career Patterns Among Black American Doctorates: A Note on the "Brain Drain" Hypothesis Journal of Negro Education, Vol. 42, No. 2. pp. 191-204.

232) Mommsen K G (1974) Black Ph.D.s in the Academic Marketplace: Supply, Demand, and Price Journal of Higher Education, 45, 4, pp. 253-267.

233) Morauta L (1979) Indigenous Anthropology in Papua New Guinea Current Anthropology, 20, 3, pp. $561-576$. 
234) Moravcsik, M. J. and S. G. Gibson (1979) The dynamics of scientific manpower and output. Research Policy, Volume 8, 1, Pages 26-45

235) Morris, E. W., (1972), The Contemporary Negro College and the Brain Drain, Journal of Negro Education, Vol. 41, No. 4. pp. 309-319.

236) Mountford, A. (1997) Can a brain drain be good for growth in the source economy? Journal of Development Economics, Volume 53, 2, Pages 287-303

237) Mushkin, S. J. (1962) ed. Economics of Higher Education. Washington: Government printing office.

238) Nafziger, J. A. R. (1983), The General Admission of Aliens under International Law American Journal of International Law, 77, 4.,pp. 804-847.

239) Nett, R. (1971), The Civil Right We Are Not Ready For: The Right of Free Movement of People on the Face of the Earth Ethics, Vol. 81, No. 3. pp. 212-227.

240) Nhundu, T J (1992), A Decade of Educational Expansion in Zimbabwe: Causes, Consequences, and Policy Contradictions Journal of Negro Education, 61 (1). pp. 78-98.

241) Nye J S, Jr. and R. O. Keohane (1971), Transnational Relations and World Politics: A Conclusion (in Toward Peace and Justice?) International Organization, 25, 3, Transnational Relations and World Politics. pp. 721-748.

242) Oberschall, A. (1996), The Great Transition: China, Hungary, and Sociology Exit Socialism Into the Market (in Symposium on Market Transition) American Journal of Sociology, Vol. 101, No. 4. pp. 1028-1041.

243) O'Hearn, D (1994), Innovation and the World-System Hierarchy: British Subjugation of the Irish Cotton Industry, 1780-1830 American Journal of Sociology, Vol. 100, No. 3. pp. 587-621.

244) Oldman, O. and R. Pomp (1975) The brain drain: A tax analysis of the Bhagwati proposal. World Development, Volume 3, 10, Pages 751-763

245) O'Rourke K (1992) Why Ireland Emigrated: A Positive Theory of Factor Flows Oxford Economic Papers, 44, 2.,pp. 322-340.

246) Oteiza, Enrique, (1965), Emigration of engineers from Argentina: A case of Latin American “Brain Drain”, International Labor Review, 92, 6.

247) Palfreeman A C (1974), Non-White Immigration to Australia Pacific Affairs, 47(3) 344-357.

248) Palley D B (1976) Resolving the Nonresident Student Problem: Two Federal Proposals Journal of Higher Education, V47, 1, pp. 1-31.

249) Partington, M. (1975) The brain drain tax proposal: A lawyer's view. World Development, Volume 3 , 10, Pages 717-749

250) Pastor Robert A. (1974), The Platonic Acorn: A Case Study of the United Nations Volunteers International Organization, Vol. 28, No. 3. pp. 375-397.

251) Patinkin, Don A 'Nationalist' Model in W. Adams ed. The Brain drain, NY, Macmillan.

252) Streeten, P. (1974) The limits of development research. World Development, 2, 10-12, Oct. Pages 11-34

253) Pavitt, K. (1973), Technology, International Competition, and Economic Growth: Some Lessons and Perspectives World Politics, Vol. 25, No. 2. pp. 183-205.

254) Pedraza, S (1991) Women and Migration: The Social Consequences of Gender Annual Review of Sociology, 17, pp. 303-325.

255) Penaloza, L. (1994), Atravesando Fronteras/Border Crossings: A Critical Ethnographic Exploration of the Consumer Acculturation of Mexican Immigrants The Journal of Consumer Research, 21, 1, pp. 32-54.

256) Perri, T. J. (1985) Wage prospects and the existence of job queues when the wage is a sorting device. Economics Letters, Volume 17, 1-2, Pages 157-159.

257) Petersen W. (1978), International Migration Annual Review of Sociology, 4. pp. 533-575.

258) Pierre P. A. and E. P. Adams (1987) Combating Minority Brain Drain Educational Record 68 (2): $48-53$.

259) Ponder, H et alia. (1994), How I Would Spend a \$30 Million Grant for African-American Higher Education The Journal of Blacks in Higher Education, 3, pp. 86-91.

260) Population and the World Employment Conference (in Notes and Commentary) DH Population and Development Review, Vol. 2, No. 3/4. pp. 502-505, (1976).

261) Population Brief: Latin America (in Data and Perspectives), (1980).

262) Portes, A. (1976) Determinants of the Brain Drain. In Kubat, D. (ed) The Politics of the Return: International Return Migration in Europe. Centre for Migration Studies New York, pp. 269-275.

263) Portes, A. and A. Stepick (1985), Unwelcome Immigrants: The Labor Market Experiences of 1980 (Mariel) Cuban and Haitian Refugees in South Florida American Sociological Review, 50, 4, pp. 493-514.

264) President Swygert Takes the Helm at Howard University (in News and Views) The Journal of Blacks in Higher Education, No. 8.), pp. 32-34, (1995).

265) Program of Action of the 1994 International Conference on Population and Development (Chapters IX-XVI) (in Documents) Population and Development Review, Vol. 21, No. 2. pp. 437-461 (1995).

266) Psacharopoulos, G. (1975) Estimating some key parameters in the brain drain taxation model. Journal of Development Economics, Volume 2, 3, Pages 309-318

267) Quah, S. R (1989), The Social Position and Internal Organization of the Medical Profession in the Third World: The Case of Singapore Journal of Health and Social Behavior, 30 (4), Theme: Sociological Studies of Third World Health and Health Care. pp. 450-466. 
268) Radhakrishnan, R. (1993), Postcoloniality and The Boundaries of Identity Callaloo, Vol. 16, No. 4, On "PostColonial Discourse": A Special Issue. pp. 750-771.

269) Rauch, J. E. (1991), Reconciling the Pattern of Trade with the Pattern of Migration. The American Economic Review, 81, 4, pp. 775-796.

270) Reichlin, P. and A. Rustichini (1998) Diverging patterns with endogenous labor migration Journal of Economic Dynamics and Control, Volume 22, Issue 5, May 1998, Pages 703-728

271) Reubens, E. P. (1983), International Migration Models and Policies (in Economics of Mass Migration from Poor to Rich Countries) The American Economic Review, Vol. 73, No. 2, Papers and Proceedings of the NinetyFifth Annual Meeting of the American Economic Association. pp. 178-182.

272) Reynolds C W; R K McCleery (1988) The Political Economy of Immigration Law: Impact of Simpson-Rodino on the United States and Mexico (in Symposia: Immigration) The Journal of Economic Perspectives, 2, 3, $117-131$.

273) Rhoades R. E. (1977), Intra-European Migration and Development in the Mediterranean Basin (in Research Conclusions) Current Anthropology, Vol. 18, No. 3. pp. 539-540.

274) Rhode B. (1991) East-West migration / Brain Drain cost. Social Sciences, Brussels EC commission.

275) Rivera-Batiz, F. L. (1983) International migration, non-traded goods and economic welfare in the source country. Journal of Development Economics, Volume 11, 1, Pages 81-90

276) Rivera-Batiz, F. L. (1983) The service sector, monopolistic competition and the impact of emigration. Economics Letters, Volume 12, 3-4, Pages 327-332

277) Robinson, E. H. (1974), The Early Diffusion of Steam Power The Journal of Economic History, Vol. 34, No. 1, The Tasks of Economic History. pp. 91-107.

278) Rodriguez, C. A. (1975a) On the welfare aspects of international migration JPE 83, 1065-72

279) Rodriquez, C. A. (1975b) Brain Drain and economic growth : a dynamic model. Journal of development in economics, 2. 223-247

280) Romans T. (1974): Benefits and Burdens of Migration (with special reference to the Brain Drain) Southern Econ J. 40 447-55.

281) Romer, P M (1986) Increasing Returns and Long-Run Growth The Journal of Political Economy, 94, 5, 10021037.

282) Romer, P M (1987) Growth based on increasing returns due to specialization American Economic review, 77 , p 56-62.

283) Romer, P M. (1990) Endogenous technological change, Journal of Political economy, 98, p 71-108.

284) Roscher, W G F (1878) ed. Principles of Political Economy. Translated by JJ Lalor. Chicago: Callaghan \& Co.

285) Rostow W. W. (1985a), Is There Need for Economic Leadership?: Japanese or U.S.? (in The Pacific Challenge For World Economic Leadership) The American Economic Review, Vol. 75, No. 2, Papers and Proceedings of the Ninety-Seventh Annual Meeting of the American Economic Association. pp. 285-291.

286) Rostow W. W. (1985b), The World Economy Since 1945: A Stylized Historical Analysis The Economic History Review, New Series, Vol. 38, No. 2. pp. 252-275.

287) Ruggie, J G (1972), Collective Goods and Future International Collaboration The American Political Science Review, Vol. 66, No. 3. pp. 874-893.

288) Said, E. W. (1991), Identity, Authority, and Freedom: The Potentate and the Traveler (in Positions) Transition, No. 54. pp. 4-18.

289) Salt, J C, (1997) International movements of the highly skilled. OECD Occasional Papers 3.

290) Salt J C, (2001) Current Trends in International Migration in Europe. CDMG, 33.

291) Salt J C et alia (1999). Assessment of possible migration pressure and its Labour market impact following EU enlargement to Central and Eastern Europe: part II, London HMSO.

292) Sathyamurthy T. V. (1973), Social Anthropology in the Political Study of New Nation-States Current Anthropology, Vol. 14, No. 5. pp. 557-579.

293) Sauvy, A (1966) The Population Situation in Europe Address to the opening sitting on the European Population Conference, Strasburg, Doc. CDE (66) 5/3.

294) Say, J-B. (1821) ed. A treatise on Political Economy. Vol I Translated by C. R. Prinsep. Boston: Wells \& Lilly.

295) Scheffel, D (1990), In Search of Poland's Old Believers Anthropology Today, 6, (5) 2-8.

296) Schultz, T. W. (1959) Investment in man: an economist's view. Social Service Rev. XXXIII, 109-17.

297) Schultz, T. W. (1960).Capital Formation by Education JPE, vol LXVIII

298) Scott A. (1970) The Brain Drain is a human capital approach justified? In Education, Income and Human Capital, ed. W. Lee Hansen (NY: National Bureau of Economic Research)

299) Scott, A (1993) Does Living in Canada Make One a Canadian Economist? (in CEA Twenty-Fifth Anniversary Symposium) The Canadian Journal of Economics, Vol. 26, No. 1. pp. 26-38.

300) Shaw, R. P. (1981) Manpower and educational shortages in the Arab world: An interim strategy. World Development, Volume 9, 7, Pages 637-655

301) Sherman, Mary Antoinette Brown (1990), The University in Modern Africa: Toward the Twenty-First Century Journal of Higher Education, Vol. 61, No. 4. pp. 363-385.

302) Shore, C. (1992), Virgin Births and Sterile Debates: Anthropology and the New Reproductive Technologies Current Anthropology, Vol. 33, No. 3. pp. 295-314. 
303) Sidgwick, H. (1901). ed. The principles of political economy. London : Macmillan \& Co.

304) Simon J L and A M Pilarski (1979), The Effect of Population Growth Upon the Quantity of Education Children Receive The Review of Economics and Statistics, 61 (4). pp. 572-584.

305) Sjaastad, L A (1962) The costs and returns of Human Migration. Journal of Political Economy.

306) Skeldon R (Winter, 1990-1991), Emigration and the Future of Hong Kong Pacific Affairs, 63, 4, $500-523$.

307) Smith, A. (1937) ed. The Wealth of Nations. New York: modern library.

308) Spear, Bruce (1993), Multiculturalism, Inc. (in Positions) Transition, No. 61. pp. 72-86.

309) Spivak, Gayatri Chakravorty (1981), French Feminism in an International Frame (in The Politics of Theory, The Theory of Politics: The Transdisciplinary Questioning) Yale French Studies, No. 62, Feminist Readings: French Texts/American Contexts. pp. 154-184.

310) Stark, O. and Y. Wang (2002) Inducing human capital formation: migration as a substitute for subsidies. Journal of Public Economics, Volume 86, 1, Pages 29-46

311) Stark, O., C. Helmenstein and A. Prskawetz (1997) A brain gain with a brain drain. Economics Letters, Volume 55, 2, Pages 227-234

312) Stark, O., C. Helmenstein and A. Prskawetz (1998) Human capita formation, human capital depletion, and migration: a blessing or a 'curse'? Economics Letters, Volume 60, 3, Pages 1291-1309

313) Stark, O (2004) Rethinking the Brain Drain. World Development, Volume 32, 1, Pages 15-22

314) Stavis B (1990) Contradictions in Communist Reform: China before 4 June 1989 Political Science Quarterly, 105, 1, pp. 31-52.

315) Stone Richard (1972), A Markovian Education Model and Other Examples Linking Social Behaviour to the Economy Journal of the Royal Statistical Society. Series A (General), Vol. 135, No. 4. pp. 511-544.

316) Straubhaar T (2000) International mobility of the highly skilled: Brain Gain, Brain Drain or Brain Exchange. HWWA discussion paper of Hamburg.

317) Straubhaar T and M R Wolburg (1999) Brain Drain and Brain Gain in Europe: an evaluation of the EastEuropean Migration to Germany. Jahrbücher für Nationalökonomie und Statistik, vol 218, N 5-6.

318) Streeten, P. (1974), Social Science Research on Development: Some Problems in the Use and Transfer of an Intellectual Technology J. of Economic Literature, 12 (4) 1290-1300.

319) Streeten, P. (1980) Basic needs and human rights. World Development, Volume 8, 2, Pages 107-111

320) Suleiman, M. W. (1973), Attitudes of the Arab Elite Toward Palestine and Israel The American Political Science Review, Vol. 67, No. 2. pp. 482-489.

321) Svejnar, J. (1991), Microeconomic Issues in the Transition to a Market Economy (in Symposium on Economic Transition in the Soviet Union and Eastern Europe) The Journal of Economic Perspectives, 5, 4, pp. 123-138.

322) Tabah, L. (1984), Preparations for the 1984 International Conference on Population (in Notes and Commentary) Population and Development Review, Vol. 10, No. 1. pp. 81-86.

323) The 1972 Meeting of the Population Association (in Current Items) Population Index, 38,3, 249-305, (1972).

324) The 1974 Meeting of the Population Association (in Current Items) Population Index, 40,3, 391-467 (1974).

325) The Cocoyoc Declaration International Organization, 29, 3, International Responses to Technology. pp. 893901, (1975).

326) The International Conference on Population, 1984 (in Documents) [The International Conference on Population, convened by the United Nations] Population and Development Review, 10, 4, pp. 755-782, (1984).

327) The international Migration of talent and Skills (Washington 1966) Proceedings of a Workshop and Conference sponsored by the Council on International Affairs and Cultural Affairs of the US Government.

328) The United Nations on the Social Situation in Africa (in Documents)[The Secretary-General of the United Nations] Population and Development Review, 17, (4). pp. 749-751 (1991).

329) Thompson J D (1974) Technology, Polity, and Societal Development Administrative Science Quarterly, 19, 1, pp. 6-21.

330) Thünen, J. H. von (1875) ed. Der isolierte Staat. Vol II part II Translated by B. F. Hoseliz . Chicago: Comparative Education Centre, Univ. of Chicago.

331) Tinto V (1982) Limits of Theory and Practice in Student Attrition Journal of Higher Education, 53 (6) $687-700$.

332) Turkcan, E. (1974) The limits of science policy in a developing country: the Turkish case a study based on the experience of the scientific and technical research council of Turkey. Research Policy, Volume 2, 4. Pages 336-363

333) Udofia, O E (1984) Imperialism in Africa: A Case of Multinational Corporations Journal of Black Studies, 14 (3) 353-368.

334) United Nations General Assembly Resolution 3362 (S-VII), September 16, 1975: Development and International Economic Cooporation (in Official Documents) American Journal of International Law,70,1 $204-216$.

335) USA Congress, Committee on government operations, scientific Brain Drain from the developing countries. (1968)

336) USA Congress, Subcommittee. The BD of scientists, engineers and Physicians from the developing countries into the United States. (1968)

337) Usher D (1977), Public Property and the Effects of Migration upon Other Residents of the Migrants' Countries of Origin and Destination The J. of Political Economy, 85(5)1001-1020. 
338) Vagts, Detlev F. (1995), The Proposed Expatriation Tax--A Human Rights Violation? (in Editorial Comment) American Journal of International Law, Vol. 89, No. 3. pp. 578-580.

339) Vega, W A and R G Rumbaut (1991) Ethnic Minorities and Mental Health Annual Review of Sociology, 17, pp. 351-383.

340) Vicziany M (1982) Coercion in a Soft State: The Family-Planning Program of India: Part I: The Myth of Voluntarism Pacific Affairs, 55, 3, pp. 373-402.

341) Vida, J.-P. (1998) The effect of emigration on human capitalformation. Journal of Population Economics 11 (4). 589-600.

342) Walle van de, E. and L. Kantrow (1974) Historical Demography: A Bibliographical Essay (in Current Items) Population Index, Vol. 40, No. 4. pp. 611-623.

343) Walras, L.(1954) ed. Elements of Pure Economics. Translated by W. Jaffè. Homewood, Ill.: R. D. Irwin, Inc.

344) Watanabe, S. (1969) The Brain Drain from developing Countries to developed Countries International Labour Review 4: 400-435.

345) Watson W B and R J Lapham (1975), Introduction Studies in Family Planning, 6, (8), Family Planning Programs: World Review 1974. pp. 207-220.

346) Weaver F. S.; D. V. Davidson and R. Torres (1992), Black Public Colleges and Universities: A Review of Institutional Options, Journal of Black Studies, Vol. 22, No. 4. pp. 494-509.

347) Webb, M. A (1985) Migration and education subsidies by governments : A game-theoretic analysis Journal of Public Economics, Volume 26, 2, Pages 249-262

348) Wei-cheng, W. V. (Winter, 1995-1996), Developing the Information Industry in Taiwan: Entrepreneurial State, Guerrilla Capitalists, and Accommodative Technologists Pacific Affairs, 68, 4, pp. 551-576.

349) Weiner, M. (1982), International Migration and Development: Indians in the Persian Gulf Population and Development Review, Vol. 8, No. 1.pp. 1-36.

350) Weisbrad, B. A. (1964) External Benefits of Public Education: An Economic Analysis, Research report 105, Industrial relation section, Princeton University.

351) Wenez G and D Ronfeldt (1991) The current situation in Mexican Immigration Science 251, 8, $1189-1193$.

352) Weston B H (1981) The Charter of Economic Rights and Duties of States and the Deprivation of ForeignOwned Wealth (in The International Law of Expropriation) American Journal of International Law,75, 3, 437-475.

353) Whelan F G (1981) Citizenship and the Right to Leave The American Political Science Review,75, 3, 636-653.

354) Whelan J. (1974) Brain Drain: A study of the persistent issue of international scientific mobility Washington $\mathrm{DC}$

355) Wilson James A (1966) The Immigration of British Scientists, Minerva 5 (1)

356) Wilson, John Douglas (1992), Optimal Income Taxation and International Personal Mobility (in International Factor Mobility: New Issues) The American Economic Review, Vol. 82, No. 2, Papers and Proceedings of the Hundred and Fourth Annual Meeting of the American Economic Association. pp. 191-196.

357) Wolburg, M (1996) On Brain Drain, Brain Exchange, Division of Labour and economic growth within Common Market. University of the federal Armed forces, Hamburg, Discussion Papers in Economic Policy, 66.

358) Wolburg, M (1997) On Brain Drain, Brain Exchange within Europe. in progress.

359) Wolburg, M and A Wolter (1997) Mobility within and into European Union: Some Stylized Facts. Discussion Paper of the Europa-Kolleg Hamburg.

360) Wong, K-Y (1986), The Economic Analysis of International Migration: A Generalization The Canadian Journal of Economics, Vol. 19, No. 2. pp. 357-362.

361) Wong, K-Y (1983) On choosing among trade in goods and international capital and labor mobility : A theoretical analysis. Journal of International Economics, Volume 14, 3-4, Pages 223-250

362) Wong, K. and C. K. Yip (1999) Education, Economic Growth and Brain Drain Journal of Economic Dynamics Control, 23 (5-6), pp. 699-796.

363) Wong, K. and C. Kee Yip (1999) Education, economic growth, and brain drain. Journal of Economic Dynamics and Control, Volume 23, 5-6, Pages 699-726

364) Wood B (1989), An Interview with Phillip Tobias (in Reports) Current Anthropology, 30, 2, pp. $215-224$.

365) Woodhall, M. (1987) Financing student flows: The effects of recent policy trends. Economics of Education Review, Volume 6, 2, Pages 195-204

366) Wooton, I. (1985) Labour migration in a model of North-South trade. Economic Modelling, Volume 2, 4, Pages 339-346

367) World Population Plan of Action Studies in Family Planning, 5(12) 381-392 (1974)

368) World Population Plan of Action (in Documents) [The World Population Conference] Population and Development Review, Vol. 1, No. 1. pp. 163-181 (1975).

369) Zack-Williams, A B (1997) African Diaspora Conditioning: The Case of Liverpool Journal of Black Studies, 27,4, pp. 528-542.

370) Zhang, W. (1990) Brain drain and economic cycles with international migration : A case of minimum wage in the unskilled sector. Journal of Development Economics, Volume 32, 1, Pages 191-203

371) Zhiduan Deng (1992) China's Brain Drain Problem: causes, consequences and policy options The Journal of Contemporary China, 1, pp 6-33. 